\title{
El festín antropofágico de los indios tupinambá en los grabados de Theodoro De Bry, 1592
}

\author{
Yobenj Aucardo Chicangana \\ Universidad Nacional de Colombia, sede Medellín \\ yobenj@gmail.com
}

\begin{abstract}
Resumen
Este artículo aborda el estudio de la iconografía dedicada a los rituales antropofágicos de los indios tupinambá. Específicamente, se examinan cinco grabados que muestran detalladamente la muerte, preparación y consumo de la víctima, realizados por el grabador y editor reformado Theodoro De Bry para su Americae Tertia Pars (1592). Es el tercer volumen de la colección Grandes Viajes, dedicado a los viajes al Brasil del alemán Hans Staden y del francés Jean de Léry durante la segunda mitad del siglo XVI.

Palabras clave: ANTROPOFAGIA, THEODORO DE BRY, SIGLO XVII, BRASIL, TUPINAMBÁ.
\end{abstract}

\begin{abstract}
This article addresses the iconography of anthropophagic rituals amongst the Tupinambá indians. More specifically, it examines five engravings by engraver and reformist editor Theodore de Bry for his Americae Tertia Pars (1592), where the death, preparation and consumption of the victim are deícted in detail. This is the third volume of the Great Voyages collection dedicated to the voyages to Brazil by the German soldier Hans Staden, and frenchman Jean de Léry.

Key words: ANTRHROPOPHAGY, THEODOR DE BRY, $17^{\mathrm{TH}}$ CENTURY, BRASIL, TUPINAMBÁ.
\end{abstract}


En 1590, el flamenco, grabador, editor y librero hugonote nacido en Liège, Theodoro De Bry (1528-1598), daría inicio a su colección Thesaurus de Viajes o Collectionnes Peregrinatorum in Indiam Occidentalem et Indian Orientalem, más conocida popularmente como los Grandes Viajes ${ }^{1}$. El gigantesco proyecto editorial de los Grandes Viajes formaría parte de un nuevo tipo de ediciones que, al final del siglo XVI, se caracterizaban por ser bien cuidadas, hechas en menor tiempo ${ }^{2}$ y con una mayor calidad y preocupación por los grabados ${ }^{3}$, ahora hechos en metal ${ }^{4}$, así como por mejores técnicas de reproducción e impresión ${ }^{5}$. La mejoría en la calidad

\footnotetext{
${ }^{1}$ Vale la pena aclarar que esta distinción de grandes y pequeños viajes se debe al formato de la presentación de las ediciones y no a la extensión de los viajes. Los Grandes Viajes son dedicados a las narrativas del Nuevo Mundo y los Pequeños Viajes a las Indias Orientales. Los primeros fueron publicados entre 1590 y 1634, en total 13 volúmenes, y los segundos constan de 13 partes.

${ }^{2}$ Antes del siglo XV, elaborar un manuscrito era un trabajo minucioso y llevaba mucho tiempo. Cualquier copia del mismo manuscrito era hecha de forma artesanal, demorando el mismo tiempo del original, muchas veces hasta años. Cuando el texto tenía iluminaciones, era un trabajo aún más dispendioso, debido al cuidado que se debía tener, ya que era una labor delicada (miniaturas) y se hacía manualmente, elemento por elemento. De ese modo, es posible imaginar que 10 copias de un manuscrito con iluminaciones tomara años y no se podría tener certeza de su conclusión. Si los manuscritos llevaban tiempo para ser hechos, lo mismo ocurría con las pinturas y esculturas. Quien conoce el proceso de las pinturas al óleo sabe que, por ser un pigmento aglutinado con óleo de linaza, el tiempo de secado es muy largo, precisamente para poder ser más trabajado, en contraste con la témpera, que tiene un proceso de secado muy rápido. Con el surgimiento de la pintura al óleo, las obras de arte del Renacimiento llevaban meses para ser concluidas y estas acababan en iglesias o grandes palacios, donde tenían siempre un lugar para ser "expuestas" a un público limitado al círculo del mecenas o de la comunidad que frecuentara la iglesia.

${ }^{3}$ El grabado funcionaba como un sello: a partir de una matriz en madera (xilograbado), piedra (litograbado) o metal (grabado) era "entintada" y, por presión, la imagen era copiada en espejo en el papel. Las estampas hechas en una matriz de madera eran fácilmente reconocibles debido a su acabamiento grosero, líneas gruesas y pocos detalles o volumen, especialmente al ser comparadas con las hechas en láminas de metal.

${ }^{4}$ En el siglo XV y parte del XVI, la mayoría de los grabados eran hechos en madera; con el desarrollo de la técnica comenzaron a ser usadas matrices en diversos materiales, como cobre, donde el dibujo era tallado en la lámina y después era expuesto a ácidos, consiguiendo texturas variadas. Las partes de la lámina que no deberían ser tocadas por los ácidos eran cubiertas con cera. A partir de esta matriz de metal era posible obtener una infinidad de copias, hasta que se desgastaran. De ese modo, la matriz de metal ofrecía mejores opciones y más durabilidad que las de madera.

${ }^{5}$ William M. Luins, Jr. Prints and visual communication (Cambridge: The MitPress, 1982), 160; Chandra Mukerji, From Graven Images. Patterns of Modern Materialism (Nueva York: Columbia University Press, 1983), 65, y Elizabeth L. Eisentein, A Revolução da Cultura Impressa. Os primórdios da Europa Moderna (São Paulo: Ática, 1998), 38-41.
} 
de las ilustraciones ${ }^{6}$ hizo que estas se destacaran y dejeran de ser apenas simples complementos de los textos. Chandra Mukerji afirma que los libros ilustrados ganaron mayor difusión y se convirtieron en un método sofisticado de comunicación no solo por ayudar a la simple lectura de semianalfabetos, sino también por atender la demanda de una élite cultural:

A finales del siglo XVI el uso de los impresos comenzó a cambiar a medida que las ilustraciones de los libros se convertían en un método más sofisticado de comunicación, central en la producción de los mejores libros. Las nuevas ilustraciones, que se encuentran principalmente en libros sobre la naturaleza, arquitectura, pintura e ingeniería, eran diferentes a sus sencillas predecesoras. En lugar de atraer audiencias semialfabetizadas aliviando el tedio del texto verbal, fueron concebidas para proporcionar información pertinente y ayudar al experto a entender las ideas escritas. De esta manera, las ilustraciones se volvieron parte de la cultura de élite ${ }^{7}$.

El impacto de la imprenta en Europa y su popularización ${ }^{8}$ hicieron que también fuera utilizada como vehículo de propaganda tanto por los protestantes como por los católicos ${ }^{9}$. El protestantismo fue pionero en explorar su potencial como medio

\footnotetext{
${ }^{6}$ Si la imprenta generó un proceso de transformaciones en la escritura; el grabado va a generar una "revolución" en el uso de la imagen en la Europa de los siglos XV y XVI. La imprenta y los diferentes tipos de grabados promovieron un gran desarrollo, más allá de la difusión de la escritura y de las imágenes, y permitieron no solamente reproducir infinidad de copias a partir de un original, sino también reducir el tiempo. Como ejemplo, se tiene la carta atribuida a Américo Vespuccio, la Qvattvor Navigationes, editada en Saint-Dié el 7 de abril de 1507. Durante ese año, la edición tuvo siete reimpresiones. Fue un éxito editorial para la época y algo impensado dos siglos antes, por el tiraje de ejemplares y por el tiempo empleado. Américo Vespuccio, Novo Mundo. As cartas que batizaram a América (São Paulo: Planeta, 2003), 58. Véase también Einsenstein, A Revolução, 57-60.

${ }^{7}$ Mukerji, From Graven Images, 66. Traducido del portugués por el editor (en adelante, TE).

${ }^{8}$ El uso del grabado para ilustrar imágenes en libros acabó por rescatar las de la tradición medieval o iluminaciones que llenaban los manuscritos, pero también popularizó las obras de los artistas más famosos. Si a algún príncipe le gustaba una determinada obra, podía solicitar una copia a su pintor de corte, que la confeccionaba, sin necesitar ir hasta el original, con ayuda de los grabados de obras "famosas". Muchos artistas usaban las estampas que veían en los libros para componer sus obras y muchos otros las alteraban y "reciclaban" para ilustrar sus propios libros. Ibídem, 57-58. Sobre la ampliación del público lector, véase el capítulo 4: "A Expansão da República das Letras". Eisenstein, A Revolução, $109-125$.

${ }^{9}$ Como hugonote fervoroso, Theodoro De Bry siempre tuvo interés en ilustrar obras que registraran las atrocidades cometidas por los españoles católicos contra los protestantes y contra los indios del Nuevo Mundo.
} 
de masas ${ }^{10}, y$, por otro lado, el Concilio de Trento, en el siglo XVI, estipularía el uso de imágenes para la acción evangelizadora católica.

Las guerras de religión y la invasión de los Países Bajos por España obligaron a Theodoro De Bry a exiliarse en Estrasburgo, donde, al lado de Etienne Delaune, aprendería y perfeccionaría sus técnicas de dibujo y reproducción. Algún tiempo después, De Bry se estableció en Frankfurt ${ }^{11}$. De acuerdo con Mary Del Priore, "La colección denominada Grandes Viajes revela cuánto sabía este artista que una imagen es necesaria al texto, que le es un complemento indispensable y una especie de luz viva proyectada sobre la narrativa de la historia ${ }^{12}$.

Los Grandes Viajes, como también otras colecciones sobre narrativas de viaje, ejercían un atractivo, fascinaban y generaban curiosidad tanto en las élites como en el resto de la población, al tiempo que ayudaron a impulsar la colonización de las Nuevas Tierras e iniciar empresas comerciales, como Bernardette Bucher comenta:

Ampliamente leídas en el mundo de la gente educada y los coleccionistas, quienes tempranamente sintieron fascinación por los viajes de exploración, también fueron adquiridas por la clase emergente de los mercaderes y artesanos, que empezaron a comprar libros y obras de arte. Si el gusto por las historias de viajes transatlánticos perduró hasta finales del siglo XVI, no fue solamente por curiosidad, sino también porque mucha gente, aun aquella que poseía medios modestos, tenía intereses invertidos en esta clase de empresas ${ }^{13}$.

Es en este contexto de guerras religiosas y de expansión atlántica que se enmarcan los primeros volúmenes de la colección de Theodoro De Bry, que tenían, entre otras funciones, el estímulo del comercio, la colonización del Nuevo Mundo ${ }^{14}$ y la difusión del cristianismo, como Thereza Baumann afirma:

El objetivo era la publicación de textos que sensibilizaran a Isabel I para decidirse por un participación activa en los proyectos de expansión atlántica retomando el proyecto de Virginia, interrumpido en 1588, y también volver familiar a los

\footnotetext{
${ }^{10}$ Eisenstein, A Revolução, 167.

${ }^{11}$ Los principales centros de imprenta y los grabadores más famosos estaban en Alemania y en los Países Bajos.

${ }^{12}$ Mary del Priore, Esquecidos por Deus: Monstros no mundo europeu e Ibero-americano (Séculos XVI-XVIII) (São Paulo: Companhia das Letras, 2000), 82. TE.

${ }^{13}$ Bernadette Bucher, Icon and Conquest. A structural analysis of the illustrations of de Bry's Great Voyages (Chicago y Londres: The University of Chicago Press, 1981), 11. TE. 14 Ibídem, 7. Véase también Thereza Baumann, "Thesaurus de Viagens. Theodoro de Bry: identidade e alteridade na iconografia do século XVI" (Tesis doctoral, Universidad Federal Fluminense, Niterói, Brasil, 2001), 2:248.
} 
europeos la presencia de los ingleses en tierras americanas. Y, sobre todo, difundir la "verdadera" religión ${ }^{15}$.

Los Grandes Viajes, colección editada en varios volúmenes por Theodoro De Bry y sus descendientes, no servían solo para el deleite del lector sino también para incitar a la meditación sobre la bondad y la misericordia de Dios, además de los “enseñamientos que se podían sacar del espectáculo de pueblos infelices y bárbaros"16. Estaban aquí incluidos la propagación del evangelio y el fortalecimiento de la posición protestante ${ }^{17}$.

Antes de la America Tertia Pars, Theodoro De Bry ya había publicado otros dos volúmenes sobre los viajes de reformados al Nuevo Mundo. El primero de ellos fue la Admiranda Narratio $^{18}$, en 1590 , obra dedicada al primer viaje inglés a Virginia en 1585 , de Thomas Harriot, expedición instigada por el geógrafo y poeta Walter Raleigh y basada en las acuarelas de John White. Para confeccionar las estampas del primer volumen fue fundamental para Theodoro De Bry el encuentro que en 1587 tuvo en Londres con Richard Hakluvt y su posterior amistad, al igual que su colección de narrativas de viaje. Por intermedio de Hakluvt, De Bry tuvo acceso a los cuadernos de acuarelas pintados por John White ${ }^{19}$ hechos en el viaje a Virginia, compuestos por registros de mapas, flora, fauna y de los habitantes nativos, los algonquinos $^{20}$. El segundo volumen la Secvnda Pars America o Brevis Narratio, de 1591, se basó en el diario del capitán Laudonnière sobre la expedición francesa de 1565 a la Florida ${ }^{21}$. Las imágenes en las que De Bry se apoyó se inspiraron en las pinturas sobre la tribu de los timucuas hechas por Jacques Le Moyne de Morgues. Las imágenes de White y de Morgues, señala Belluzo, son importantes porque "dan cuenta de modelos de sintaxis visual y de observaciones etnográficas que irían a marcar el proyecto de De Bry" ${ }^{\prime 2}$.

\footnotetext{
${ }^{15}$ Baumann, "Thesaurus de Viagens", 2:256. TE.

${ }^{16}$ Del Priore, Esquecidos por Deus, 82, y Baumann, "Thesaurus de Viagens", 2:259.

${ }^{17}$ Baumann, "Thesaurus de Viagens", 2:259.

${ }^{18}$ Un excelente trabajo sobre Theodoro de Bry y la Admiranda Narratio, presentado en forma de guión de viaje, es el de Baumann, "Thesaurus de Viagens".

${ }^{19}$ Sobre John White y Theodoro De Bry, véase el capítulo 2, "Reading Indian Bodies", del libro de Karen Ordahl Kupperman, Indians and English. Facing off in Early America (Ithaca y Londres: Cornell University Press, 2000), 41-76.

${ }^{20}$ Theodoro De Bry obtuvo los textos originales directamente de Inglaterra y se benefició de la colección de Hackluyt sobre las narrativas de viaje de los ingleses a América, a diferencia de sus hijos, que obtuvieron los textos de las traducciones del alemán. Bucher, Icon and Conquest, 8-9.

${ }^{21}$ Théodore de Bry, Le Théâtre du Nouveau Monde. Les Grands Voyages de Théodore De Bry (París: Gallimard, 1992).

${ }_{22}$ Ana Maria de Morais Belluzzo, O Brasil dos Viajantes, 3 ed. (Río de Janeiro: Objetiva; Metalivros, 2000), 54.
} 
Durante su vida, De Bry publicaría seis partes de la gigantesca colección (15901596), y en el momento de su muerte, ocurrida en 1598, la séptima parte no llegó a terminarse. Sus sucesores, Johan Theodor y Johan Israel, publicarían las partes 7 a 9 (1598-1601). Después de la muerte de Johan Theodor, Matthäus Merian publicaría las últimas cuatro partes, de la 10 a la 13 (1619-1634). En el año de 1592, Theodoro De Bry publica la America Tertia Pars ${ }^{23}$ basado en las narrativas del alemán Hans Staden y del francés Jean de Léry sobre los viajes al Brasil conocido para la época como Francia Antártica- y los habitantes de estas tierras, los tupinambá. El análisis de este artículo se detendrá en los grabados de la tercera parte dedicada al Brasil, la America Tertia Pars, de 1592, específicamente en algunas imágenes que tratan de la antropofagia: la ejecución, preparación y consumo de la víctima.

\section{La Americae Tertia Pars y sus imágenes}

Las estampas que ilustran el tercer volumen siguen las peripecias de Hans Staden en su viaje al Brasil, y su captura, cautiverio y convivencia entre los tupinambá. Muestran las costumbres de los aborígenes, danzas, borracheras, guerras y, especialmente, el ritual antropofágico. Las ilustraciones que Theodoro De Bry hace para la Americce Tertia Pars tienen básicamente dos fuentes directas: las textuales y las iconográficas, derivadas de los relatos de la Warhafftig Historia vnd beschreibung de Hans Staden, edición de Marburg de 1557, y de la Historie d'un voyage fait en la terre du Bresil de Jean de Léry, edición de 1578, y de los xilograbados que acompañan estas ediciones ilustradas ${ }^{24}$.

El texto de Marburg trata, en su primera parte, de las aventuras del alemán Hans Staden, que acompañó las expediciones de españoles y portugueses y naufragó y permaneció nueve meses preso entre los tupinambá. La última parte está dedicada a las costumbres nativas ${ }^{25}$. El Viaje al Brasil de Hans Staden sería publicado por primera vez en Marburg, en 1557, acompañado de 53 pequeños xilograbados, hechos bajo su orientación, cuyas crudas viñetas en su mayoría servirían de base a

${ }^{23}$ El título completo es: America Tertia Pars. Memorabilē provincice Brafilice Hiftoriam continēs, germanico primum fermone fcriptam à Ioāne Stadio Homburgenfi Hefso, nunc autem latinitate donatam à Teucrio Annceo Priuatocol chanthe Po: \& Med: Addita est Narratio prosectionis Ioannis Lerij in eamdem Provinciam, quā ille initio gallice confcripfit, poftea verò Latinam fecit. His accefsit Defcriptio Morum \& Ferocitatis incolarum illius Regionis, atque Colloquium ipforum idiomate confcriptum.

${ }^{24}$ Jacques Forge, "Naissance d'une image", en L'Amérique de Théodore de Bry. Une collection de voyages Protestante du XVIe siècle, dir. Michèle Duchet (París: Centre National de la Recherche Scientifique, 1987), 105, y Bucher, Icon and Conquest, 15-16.

${ }^{25}$ Hans Staden, Viagem ao Brasil. Versão do texto de Marburg de 1557 (Río de Janeiro: Academia Brasileira de Letras, 1988). 
De Bry para las versiones de sus grabados en tallo dulce ${ }^{26}$. El texto de Jean de Léry fue publicado en 1578 y narra la expedición de Villegaignon para el establecimiento de colonias en las tierras del Brasil, entre 1556-1558 ${ }^{27}$. Esta edición estaba acompañada de xilograbados sobre las costumbres de los tupinambá. Muchas imágenes que acompañaban la primera edición de Jean de Léry fueron copiadas de las obras anteriores de fray André Thevet Lez Singularitéz de la France Antarticque $(1558)^{28}$ y La Cosmographie Universelle (1575).

Para los grabados de la America Tertia Pars, Theodoro De Bry enfocó sus ilustraciones en el cautiverio de Staden y también usó la narrativa y los grabados de Léry, especialmente los referentes a las costumbres de los tupinambá, las maneras de guerrear, los ritos antropofágicos y la religión de los nativos. El conjunto de los grabados de Theodoro De Bry de la Americce Tertia Pars puede ser organizado en tres subconjuntos, de acuerdo con las fuentes: los grabados que se apoyan en los xilograbados del relato de Staden, los basados en el relato de Léry y los que combinan xilograbados de Staden, Léry ${ }^{29}$, Thevet y otros; todo esto sumado a las modificaciones realizadas por el propio De Bry en las imágenes. Las imágenes de indios que aparecen en los xilograbados de las ediciones ilustradas de Staden, Léry y Thevet son diferentes de las hechas hasta ese momento, a mediados del siglo XVI. En el caso de Staden, las imágenes que acompañan el texto forman una serie más abundante y compleja, y no son solo imágenes sueltas.

El texto de Staden viene acompañado de grabados que detallan cuidadosamente los episodios del relato y su desarrollo temporal, mientras que Thevet y Léry están más preocupadas por mostrar en las imágenes las costumbres de los habitantes del Brasil. Obviamente, estas imágenes tienden a ser "diferentes" de las realizadas hasta ese momento; los tres viajeros estuvieron en las tierras del Brasil y vivieron o conocieron por terceros los episodios narrados. La iconografía anterior sobre la antropofagia -como la de los relatos de Vespuccio o las de la cartografía alemana-, por ejemplo, muestra un canibalismo alimentario movido por el gusto por la carne humana, mientras que las imágenes y textos de Staden, Léry y Thevet revelan la existencia de un complejo ritual de ejecución y consumo de la víctima. Aquí vale

${ }^{26}$ Grabado en tallo dulce es el que se hace en planchas de acero o cobre, en tablas de madera o sobre otra materia que fácilmente reciba la huella del buril solo con el impulso de la mano del artista.

${ }^{27}$ Jean de Léry, Viagem à terra do Brasil (Belo Horizonte y São Paulo: Livraria Itatiaia; Universidade de São Paulo, 1980).

${ }^{28}$ Thevet permaneció en Brasil entre 1555 y 1556 y publicó su obra dos años después de su retorno a Francia. Sus imágenes están entre las primeras fuentes iconográficas detalladas sobre el Brasil y sus habitantes. André Thevet, As Singularidades da França Antártica (Belo Horizonte y São Paulo: Livraria Itatiaia; Universidade de São Paulo, 1978).

${ }^{29}$ Sobre los modelos franceses de Theodoro de Bry, véase el artículo de Jean-Paul Duviols, "Théodore de Bry et ses modèles français", Caravelle (Toulouse, Francia), 58 (1992): 7-16. 
recordar una idea de Osvaldo Silva Galdames: "cuando el canibalismo aparece con relieves verídicos, se enmarca dentro de contextos ceremoniales. Allí todos los testimonios coinciden en dar una misma opinión: la ingestión de carne se conjuga con creencias mágico-religiosas ${ }^{\prime 30}$.

La novedad establecida por la iconografía del indio en las obras de Staden, Thevet y Léry integra un proceso de pasaje de lo maravilloso a lo exótico ${ }^{31}$ del que dan cuenta los xilograbados cuando muestran ceremonias y rituales complejos. En las narrativas de los viajeros al Nuevo Mundo, especialmente hasta la primera mitad del siglo XVI, existen discrepancias entre lo esperado, las expectativas (lo maravilloso) y lo experimentado. Sobre la imagen de América en el relato del alemán, Guillermo Giucci comenta: "América aparece, en el relato de Hans Staden, no solo desmitificada con relación al modelo de lo maravilloso que la recubría y deformaba, [sino] (...) reconocida en su singularidad y en su diferencia radical con el referente europeo, 32 .

Sérgio Buarque de Holanda ya había notado este pragmatismo en los portugueses, y que el desgaste de las expectativas llevó a cuestionar el imaginario como explicación de la realidad ${ }^{33}$. Así, los cambios en la iconografía pueden ser explicados en parte por el proceso de desmitificación que conducirá a la producción de imágenes más realistas, tales como las costumbres y las ceremonias de los aborígenes. Ana M. Belluzo llama la atención para que se establezca una distinción en las imágenes de Theodoro De Bry, que ella identifica como grabados de ilustración, por un lado, y de interpretación, por otro:

... los gravados de ilustración -hechos a partir de la trascripción del texto en imágen, como es el caso de las del libro de Staden- y los gravados de interpretación, que toman como base otros diseños, manipulándolos, recreando un repertorio transformado. Estos, ya practicados en el libro de Léry, apoyado en motivos visuales de la obra de Thevet, caracterizan el trabajo gráfico de De Bry, que se vale, como ya señalamos, de las ilustraciones de Staden y Léry y de las imágenes de otras expediciones a otros lugares de América.

Es ese mismo proceso de sucesivas versiones el que nos autoriza a hablar de imágenes y no de representaciones del Nuevo Mundo. No se puede admitir ningún compromiso d'après nature en estos gravados hechos a partir de informaciones de otros viajeros ${ }^{34}$.

${ }^{30}$ Osvaldo Silva Galdames, "El mito de los comedores de carne humana en América", Revista Chilena de Humanidades (Santiago), 11 (1990), 65.

${ }^{31}$ Guillermo Giucci, Viajantes do Maravilhoso. O novo Mundo (São Paulo: Companhia das Letras, 1992), 21.

${ }^{32}$ Ibídem, 215.

${ }^{33}$ Sergio Buarque de Holanda, Visão do paraíso: Motivos Edênicos no Descobrimento e Colonização do Brasil (São Paulo: Companhia Editora Nacional, 1969), 146.

${ }^{34}$ Belluzzo, O Brasil dos Viajantes, 53. TE. 
Se incorporarían, además, la tradición pictórica de las imágenes de la antropofagia medieval, las del Nuevo Mundo y las del arte de la época, de manera que las fuentes de inspiración no pueden ser restringidas únicamente a las narrativas ilustradas de viajeros. De Bry, como librero, editor y grabador, tuvo fuentes muy variadas en que apoyarse.

No concuerdo con el argumento de Ana M. Belluzzo con relación al compromiso con lo natural, pues en las imágenes realizadas en el siglo XVI este compromiso es relativo y los propios grabados de Staden, Thevet y Léry fueron hechos años después de los episodios descritos. En el caso de Léry, pasarían veinte años de haber vuelto del Brasil para publicar por primera vez su obra. Aunque haya vivido allí y fuera testigo de muchos acontecimientos descritos, esto no será impedimento para que muchos xilograbados para la primera edición ilustrada de su Historie d'un voyage fait en la terre du Bresil de 1578 fueran copiados de los xilograbados hechos para ilustrar las obras de Thevet de años anteriores, las Singularitéz de 1558 y la Cosmographie de 1575.

En la mayoría de las imágenes sobre el Nuevo Mundo los artistas no tenían ningún compromiso con lo natural. En el siglo XVI, al momento de producir un grabado, la tradición y las convenciones jugaban un papel mayor que la experiencia de observar directamente del natural, tal como Gombrich afirma: "Todo arte tiene origen en la mente humana, en nuestras reacciones al mundo más que en el mundo visible en sí $^{\prime \prime 35}$. Para la existencia de una representación no es necesario que ella tenga compromisos con lo que es directamente observado. El hecho de que tanto Léry como Staden y Thevet hayan estado en Brasil no significa que sus grabados sean más fidedignos con lo que estaba siendo observado ni etnográficamente más correctos que los hechos por Theodoro De Bry ${ }^{36}$, mientras que las imágenes de este contienen descompases entre texto e imagen, elementos nuevos que no pueden ser reducidos a simples copias de otras ediciones de viajes a América, ni explicados por las narrativas ni por los grabados en las cuales estuvo basado inicialmente. Belluzzo también ignora la posibilidad de originalidad y aporte por parte de De Bry en este proceso de copia, selección y adaptación.

La novedad de los grabados de De Bry como editor está precisamente en las divergencias, en esas imágenes que no encuentran referentes en los grabados ni en los textos de Léry y Staden y dan al lector nuevas lecturas e informaciones ${ }^{37}$. Son precisamente esos descompases entre imagen y texto los que hacen que los grabados de Theodoro De Bry sean tan interesantes y es allí donde radica la

\footnotetext{
${ }^{35}$ H. E. Gombrich, Arte e Ilusão (São Paulo: Martins Fontes, 1989), 93.

${ }^{36}$ Peter Mason, Infelicities. Representation of the Exotic (Baltimore, Estados Unidos: The Johns Hopkins University Press, 1998), 42-45.

${ }^{37}$ Ronald Raminelli, Imagens da Colonização (São Paulo: Jorge Zahar, 1996), 97.
} 
originalidad de este editor y grabador. Las respuestas para estos "desacuerdos" se encuentran en la comprensión de la tradición iconográfica del Renacimiento y en sus convenciones, sin dejar de lado el soporte "etnográfico" que las crónicas ofrecen. Se trabajará con los descompases entre imagen y texto en tres aspectos: el festín antropofágico, los cuerpos renacentistas de los indios y el protagonismo de las mujeres indias, sin perder de vista las referencias al resto del conjunto de grabados de la America Tertia Pars.

\section{El festín antropofágico tupinambá}

Tupinambá corresponde a una denominación colonial usada por los cronistas del siglo XVI y XVII para identificar a las tribus tupis que vivían en la costa del Brasil $^{38}$ y también a una de esas "naciones", como se anota en el Dicionário do Brasil Colonial:

Los tupinambás o tupis no eran homogéneos, y formaban, según los cronistas, "naciones", "castas" o "generaciones" que frecuentemente luchaban entre sí y se localizaban en puntos distintos del litoral. Los carijós eran una rama de los guaraníes y se establecían entre la laguna de los Patos y Cananéia; los tupiniquis se expandían por la altiplanicie y el litoral de São Paulo; los tupinambá propiamente dichos o tamoios se ubicaban entre el litoral norte paulista, el valle del Paraíba y Cabo Frío; los temiminós, en la bahía de Guanabara. Entre Espíritu Santo y Bahía, los indios fueron también denominados genéricamente tupiniquins; el territorio entre Bahía y la hoz del San Francisco era también dominado por los tupinambás; en cuanto a los potiguares, se distribuian por la costa del noreste hasta Ceará. En el siglo XVII, los colonos encontraron tupinambás en el Marañón, en Pará y en la isla de Tupinambarana, en el medio Amazonas ${ }^{39}$.

Desde las primeras descripciones de Colón y Vespuccio, los caribes de las Antillas y los tupinambá de la costa brasileña pasaron a ser conocidos por sus prácticas antropofágicas, como anota Metraux:

La antropofagia es una costumbre característica de los caribes y de los tupí-guaranís. Todas las tribus de esta última familia lingüística, a propósito de la cual estamos tan mal informados, se consideran como antropófagas. En la mayoría de los casos, las

38 Carlos Fausto, "Fragmentos de história e cultura tupinambá. Da etnologia como instrumento crítico de conhecimento etno-histórico", en História dos Índios do Brasil, comp. Manuela Carneiro da Cunha (São Paulo: Companhia das Letras; Secretaría Municipal de Cultura; Fapesp, 1992), 383.

39 Ronald Raminelli, "Tupinambá”, en Dicionário do Brasil Colonial (1500-1808), dir. Ronaldo Vainfas (Río de Janeiro: Objetiva, 2000), 566. Véase también Fausto, "Fragmentos", 383. TE. 
acusaciones tienen fundamento, pues en todas sus tribus el canibalismo es practicado ritualmente $e^{40}$.

En los siglos XVI y XVII, la antropofagia fue descrita detalladamente por los cronistas $^{41}$ que visitaron estas tierras. Portugueses, franceses, holandeses, alemanes y hasta las cartas de los jesuitas dieron espacio en sus narrativas para describir estas prácticas, consideradas abominables. Ya en las primeras décadas del siglo XVI, la iconografía mostró esos terribles banquetes caníbales practicados por los tupinambá en las estampas de las ediciones de viajes. En la cartografía, a partir de Waldseemüller y Fries, estas imágenes aterradoras invadieron los mapas de las tierras del Brasil.

El gran apogeo de esta iconografía sobre el canibalismo fue alcanzado en los detallados grabados hechos por Theodoro De Bry para la tercera parte de su colección de viajes sobre América. Las imágenes basadas en la narrativa de Hans Staden sobre la captura $\mathrm{y}$, especialmente, la ejecución de la víctima por los tupinambás representan el clímax de la Americce Tertia Pars. Cinco estampas muestran la ejecución, la muerte y el consumo de la víctima por los tupinambá. En la primera aparecen indias desnudas, voluptuosas, que se muestran ansiosas al morder sus propias manos y brazos. Dos concentraciones de indios a la izquierda y a la derecha asisten a la ejecución del prisionero ${ }^{42}$. Un hombre desnudo amarrado a una cuerda en el centro de la composición y sujetado por dos guerreros con escudos parece desafiar a su verdugo antes de ser sacrificado con un golpe de tacape $^{43}$, dado por el guerrero tupinambá, adornado a la izquierda del grabado (Figura 1). El relato de Hans Staden describe la escena así:

\footnotetext{
${ }^{40}$ Alfred Métraux, A Religião dos Tupinambás e suas relações com as demais tribos tupiguaranis (São Paulo: Ed. Nacional; Universidade de São Paulo, 1979), 138-139. TE.

${ }^{41}$ El ritual de la muerte del enemigo y su consumo está registrado por la mayoría de los cronistas. Staden, Viagem, 183-193; Thevet, As Singularidades, cap. 40; Léry, Viagem, 193-204; Claude D'Abbeville, História da Missão dos Padres Capuchinhos na Ilha do Maranhão e terras circunvizinhas (Belo Horizonte y São Paulo: Itatiaia; Universidade de São Paulo, 1975), 229-234; Pero de Magalhães de Gândavo, A primeira História do Brasil. História da província Santa Cruz a que vulgarmente chamamos Brasil (Río de Janeiro: Jorge Zahar, 2004), 155-168; Gabriel Soares de Souza, Tratado descritivo do Brasil em 1587 (Belo Horizonte: Itatiaia, 2000), 245-246, 251; Fernão Cardim, Tratados da Terra e Gente do Brasil, vol 2, Do princípio e origem dos índios (Lisboa: Comissão Nacional para as Comemorações dos Descobrimentos Portugueses, 1997), 159-168.

${ }^{42}$ La ejecución del prisionero dependía de la edad, según Simón de Vasconcellos: "Dos que tomam na guerra, os velhos comem logo: (carne do maior sabor para elles) os mancebos levão captivos amarrados em cordas, com grandes algazarras, à maneira de triumpho". Simão de Vasconcellos, Chronica da Companhia de Jesus do Estado de Brasil (Río de Janeiro: Typographia de João Ignácio da Silva, 1864), Libro 1, 132, 54.

${ }^{43}$ Tacape: arma usada por algunos grupos amerindios, entre ellos, los tupinambá. Era una especie de espada o maza de madera más ancha en uno de sus extremos.
} 
Aquel que debe matar al prisionero le pega en la cabeza y dice: "Sí, aquí estoy, te quiero matar, porque los tuyos también mataron a muchos de mis amigos y los devoraron". El otro le responde: "Después de muerto, tengo todavía muchos amigos que ciertamente me han de vengar". Entonces le da el matador un golpe en la nuca ${ }^{44}$.

El fragmento de la descripción de Staden justifica la "extraña" postura desafiadora de la víctima ante su verdugo en el grabado y la reafirmación del carácter de venganza de la ejecución. Jean de Léry también registra el diálogo entre la víctima y el verdugo, así como la relación de venganza entre los dos:

"Yo no estoy para fingir, fui, en efecto, valiente y asalté y vencí vuestro país y os comí". Y así continúa, hasta que su adversario, listo a matarlo, exclama: "Ahora estás en nuestro poder y serás muerto por mí y ahumado y devorado por todos". (...) La víctima entonces responde: "Mis parientes me vengarán". (...) El salvaje encargado de la ejecución levanta entonces un tacape con ambas manos y descarga tal golpe en la cabeza del pobre prisionero que cae redondo muerto, sin querer mover brazos y piernas ${ }^{45}$.

${ }^{44}$ Staden, Viagem, 189. TE.

${ }^{45}$ Léry, Viagem, 196-198. TE. 
Figura 1

Ejecución del prisionero

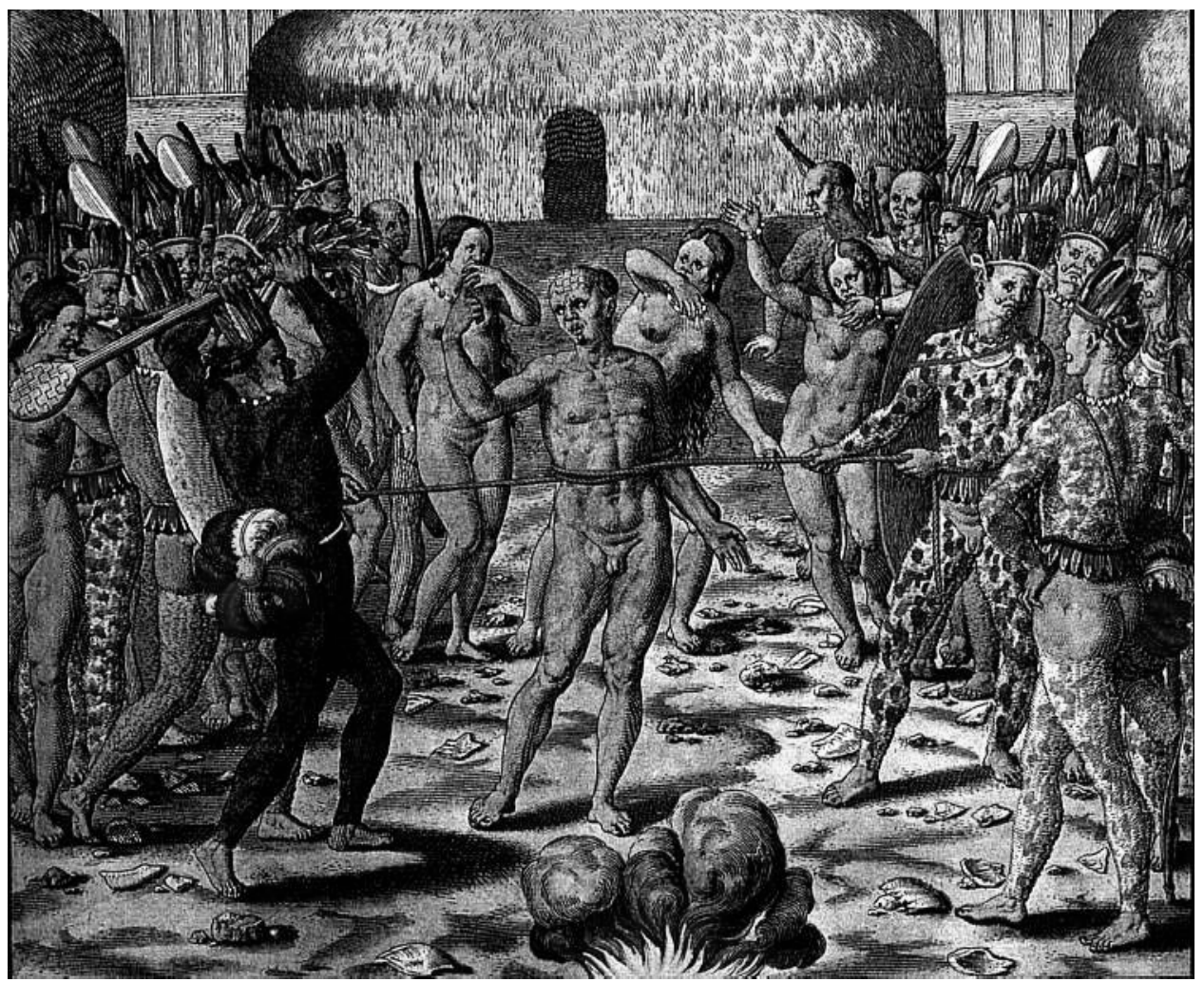

Theodore De Bry, America Tertia Pars (Frankfurt, 1592), 121. Grabado en cobre. 
En el suelo que pisan los guerreros y la víctima de la estampa de De Bry pueden notarse fragmentos de cerámica y piedras e incluso un fuego encendido. Estos fragmentos, de acuerdo con Staden, servían para que el prisionero pudiera defenderse y agredir a las mujeres que amenazaban devorarlo ${ }^{46}$. Otros cronistas dicen que a la víctima le eran dadas frutas secas para arrojar contra sus enemigos ${ }^{47}$. Estos detalles también son mencionados por Léry como justificación de la presencia de los escudos ovalados de cuero para la protección de los guerreros que sujetan a la víctima:

Después de haber estado así expuesto a la vista de todos, los dos salvajes que lo mantienen amarrado se apartan de él unas tres brazas de ambos lados y estiran fuertemente las cuerdas de modo que el prisionero quede inmovilizado. Tráenle entonces piedras y pedazos de ollas; y los dos guardas, recelosos de ser heridos, se protegen con rodelas de cuero de tapirussú y le dicen: "Véngate antes de que mueras". Comienza el prisionero a tirar proyectiles con todas sus fuerzas contra los que allí se reúnen en torno de él, algunas veces en número de tres a cuatro mil ${ }^{48}$.

El fuego es encendido por las mujeres indias a una distancia de dos pasos al frente de la víctima ${ }^{49}$ para que sea visto por ella antes de morir, y este fuego va a ser usado para preparar su cuerpo después de la muerte.

El segundo grabado muestra dos instantes diferentes, posteriores a la muerte de la víctima (Figura 2). En el primer momento, a la izquierda del grabado, la esposa del indio muerto llora sobre el cadáver; a la derecha, en un segundo momento, cuatro indias raspan la piel del muerto y una de ellas introduce un palo en el ano del sacrificado. A su lado, el agua está siendo hervida para retirarle la piel a la víctima. La lectura de los episodios de este grabado debe ser hecha de izquierda a derecha. En el centro, al fondo, de forma casi simétrica, aparece Hans Staden al lado del guerrero que sacrificó al enemigo, ricamente decorado y aún con el tacape en las manos. El cuerpo del guerrero tupinambá muestra las marcas de las víctimas sacrificadas por él, en forma de hendiduras o riscos en las piernas, brazos y pecho $^{50}$. A la derecha, se reúne un grupo de guerreros -entre ellos, los dos

\footnotetext{
${ }^{46}$ Staden, Viagem, 187.

47 "E ali lhe dão uns pomos duros, à maneira de laranjas, com que possa atirar e ofender a quem quiser...”. Gândavo, A Primeira, 158. "Imediatamente o prisioneiro, que tem as mãos livres, agarra os frutos e tudo o mais que pode pegar e atira com tôda a fôrça contra os assistentes". D’Abbeville, História, 232.

${ }^{48}$ Léry, Viagem, 194. TE.

${ }^{49}$ Staden, Viagem, 187.

${ }^{50} \mathrm{El}$ guerrero tupinambá del grabado corresponde a una descripción hecha por Léry: “ $U m$ homem nu, bem conformado e proporcionado de membros, inteiramente depilado, de cabelos tosquiados como já expliquei, com lábios e faces fendidos e enfeitados de ossos e pedras verdes, com orelhas perfuradas e igualmente adornadas, de corpo pintado, coxas e
} 
tupinambás de escudo que ayudaban a sujetar al prisionero momentos antes de ser muerto en el grabado anterior- que parecen esperar con calma, en tanto una india corre intranquila mordiendo su mano. Aquí, De Bry sugiere un contraste entre la serenidad y el control de los hombres y la ansiedad y falta de control de la mujer ${ }^{51}$. La descripción hecha por Jean de Léry ayuda a entender los dos momentos del episodio presentado en el grabado:

Inmediatamente después de muerto el prisionero, una mujer se coloca junto al cadáver y derrama un corto llanto; digo a propósito un corto llanto porque esa mujer (...) se lamenta y derrama fingidas lágrimas sobre su marido muerto, mas siempre con la esperanza de comerle un pedazo. En seguida, las otras mujeres, sobre todo las viejas, que son más golosas de carne humana y ansían la muerte de los prisioneros, llegan con agua hirviendo, refriegan y escaldan el cuerpo con el fin de arrancarle la epidermis (...) después el dueño de la víctima y algunos ayudantes abren el cuerpo y lo despresan ${ }^{52}$.

pernas riscadas de preto com o suco de jenipapo, e com colares de fragmentos de conchas pendurados ao pescoço". Léry, Viagem, 118. Resaltados del autor.

${ }^{51}$ Este contraste entre hombres y mujeres ya había sido notado por Raminelli, Imagens, 94.

${ }^{52}$ Léry, Viagem, 198. TE. 


\section{Figura 2}

\section{Hans Staden asiste a la preparación de la víctima}

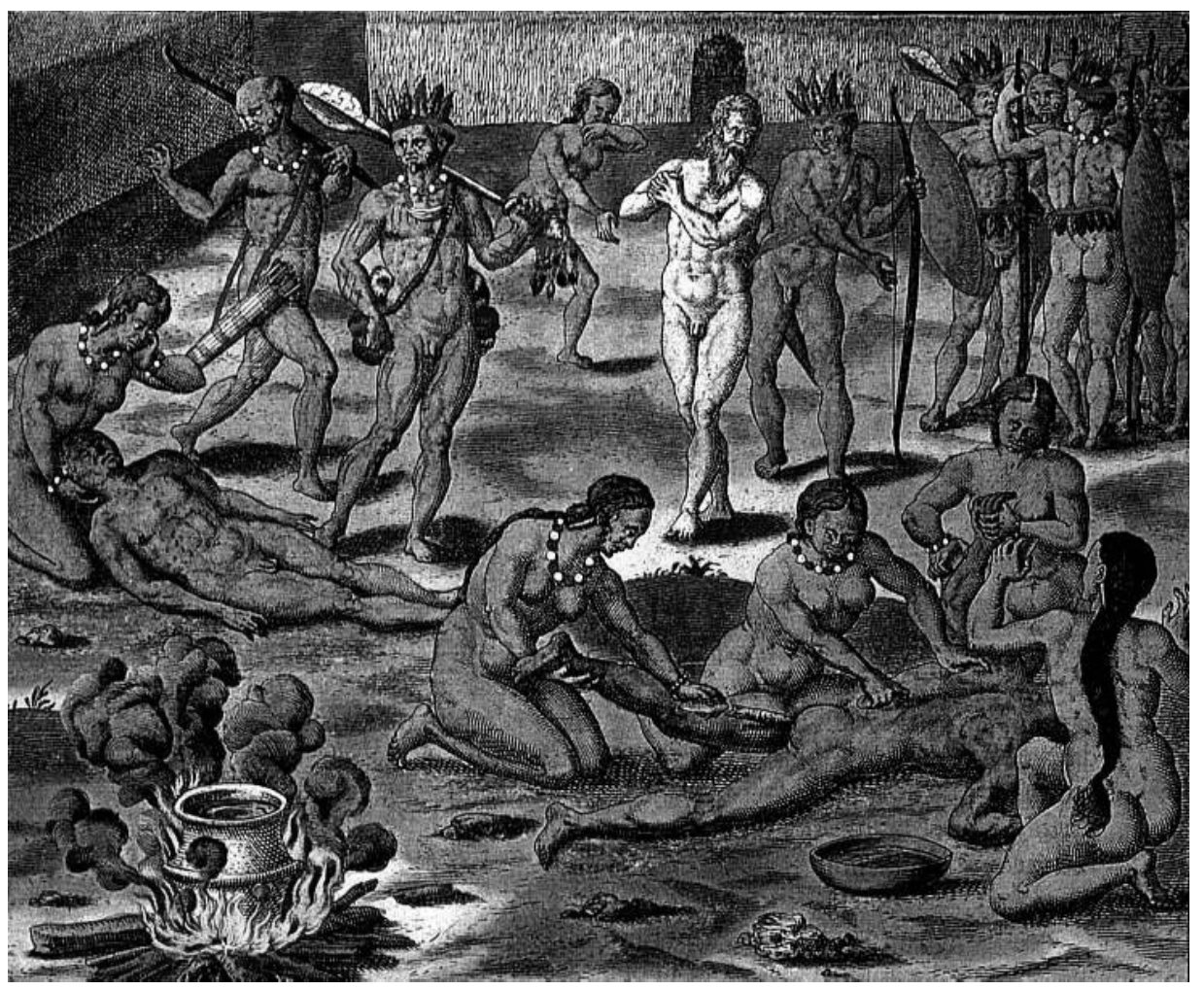

Theodore De Bry, America Tertia Pars (Frankfurt, 1592), 122. Grabado en cobre. 
Léry resalta especialmente el llanto fingido de la india por su esposo recién sacrificado, que llora, mas quiere comer un pedazo del marido ${ }^{53}$. De ese modo, las mujeres indias del grabado no se muestran solo ansiosas y descontroladas, como por ejemplo la mujer que corre en el fondo, sino también fingidas e hipócritas, como la india que llora sobre el cuerpo sin vida de la víctima. El pastor francés menciona también la presencia de mujeres viejas golosas -que no están en el grabado de Theodoro De Bry-, jóvenes y voluptuosas. Esto también justifica el motivo por el cual los hombres semejan estar esperando en el fondo el final del trabajo de las mujeres, ya que, de acuerdo con Staden y Léry, a ellos les correspondía desmembrar el cuerpo. Por lo tanto, estarían esperando que las mujeres terminen su tarea. La descripción de Léry justifica la presencia del agua hirviendo para escaldar el cuerpo, que De Bry registra tanto en el gran pote lleno de agua colocado al fuego como en la tinaja con agua al lado de las indias. El proceso de raspar la piel de la víctima también es citado por Staden: "Entonces le descarga el matador un golpe en la nuca, los sesos saltan y luego las mujeres toman el cuerpo, arrojándolo al fuego, desollándolo hasta quedar bien pelado y le introducen un palito por detrás para que nada [se] les escape" ${ }^{, 54}$.

Las descripciones de Staden y Léry coinciden en indicar que la función de escaldar la víctima correspondía a las mujeres indias. Mientras que el texto de Staden explica la presencia en el grabado del pedazo de madera que la india entierra en la víctima con ayuda de una piedra. Evidentemente, esta imagen fue confeccionada a partir de las informaciones de las narrativas de Staden y de Léry, pero no encuentra referentes directos en los xilograbados de estos relatos.

El tercer grabado presenta el desmembramiento de la víctima (Figura 3). Después de la retirada de la epidermis, los indios cortan el cuerpo. En el grabado puede verse a un indio que, con ayuda de un hacha, corta el cuerpo. Tres mujeres corren

\footnotetext{
${ }^{53}$ Era costumbre de los tupinambá tomar al prisionero como esclavo. En general, el cautivo permanecía en poder del guerrero que lo debía ejecutar o era entregado como regalo a uno de sus parientes. Después de su entrada a la aldea, el prisionero penetraba en la choza donde hubiera vivido la persona cuya tumba acabara de limpiar, recibiendo allí la red, los collares, las provisiones, las armas, todo lo dejado por el muerto. Si el difunto perecía por las armas, las viudas a veces desposaban el prisionero capturado por uno de sus parientes. Esa unión compensaba la pérdida del esposo. Si el muerto era célibe, el cautivo recibía en casamiento la hermana, la hija o incluso una de las mujeres de su dueño. Las bodas del prisionero ocurrían cerca de cinco días después de la entrada en la aldea. La mujer concedida al esclavo debía responder por él, vigilarlo y engordarlo. En caso de quedar embarazada del prisionero, después del parto, el hijo podía ser devorado inmediatamente o, en ciertos casos, se permitía que creciera hasta determinada edad y se realizaban entonces los mismos rituales de sacrificio, por ser considerado enemigo, como su padre. La mujer era la primera, en los dos casos, en probar la carne de la víctima, ya fuera el marido o el hijo. Métraux, A Religião, 114-123.
}

${ }^{54}$ Staden, Viagem, 189. TE. 
por la aldea llevando en sus manos los brazos y piernas cortadas, con enorme alegría. Otro indio abre la víctima por el medio y le retira las vísceras, que son recibidas por una india en una especie de plato. Paralelamente, dos indias ya están cocinando las vísceras y la cabeza en una enorme olla de barro, mientras otra trae leña para alimentar el fuego. En esta escena macabra pueden ser vistos niños, uno de ellos con una cabeza cortada en las manos, mientras otros dos ayudan a mantener el fuego encendido. Hans Staden afirma que:

Una vez desollado, un hombre lo toma y le corta las piernas, encima de las rodillas, y también los brazos. Vienen entonces las mujeres, pegan los cuatro pedazos y corren alrededor de las cabañas, haciendo gran vocerío. Después le abren las costillas, que separan del lado de enfrente y las reparten entre sí; mas las mujeres guardan los intestinos, cocinándolos, y del caldo hacen una sopa que se llama mingau ${ }^{55}$.

${ }^{55}$ Ibídem, 190. TE. 
Figura 3

Desmembramiento del cuerpo de la víctima

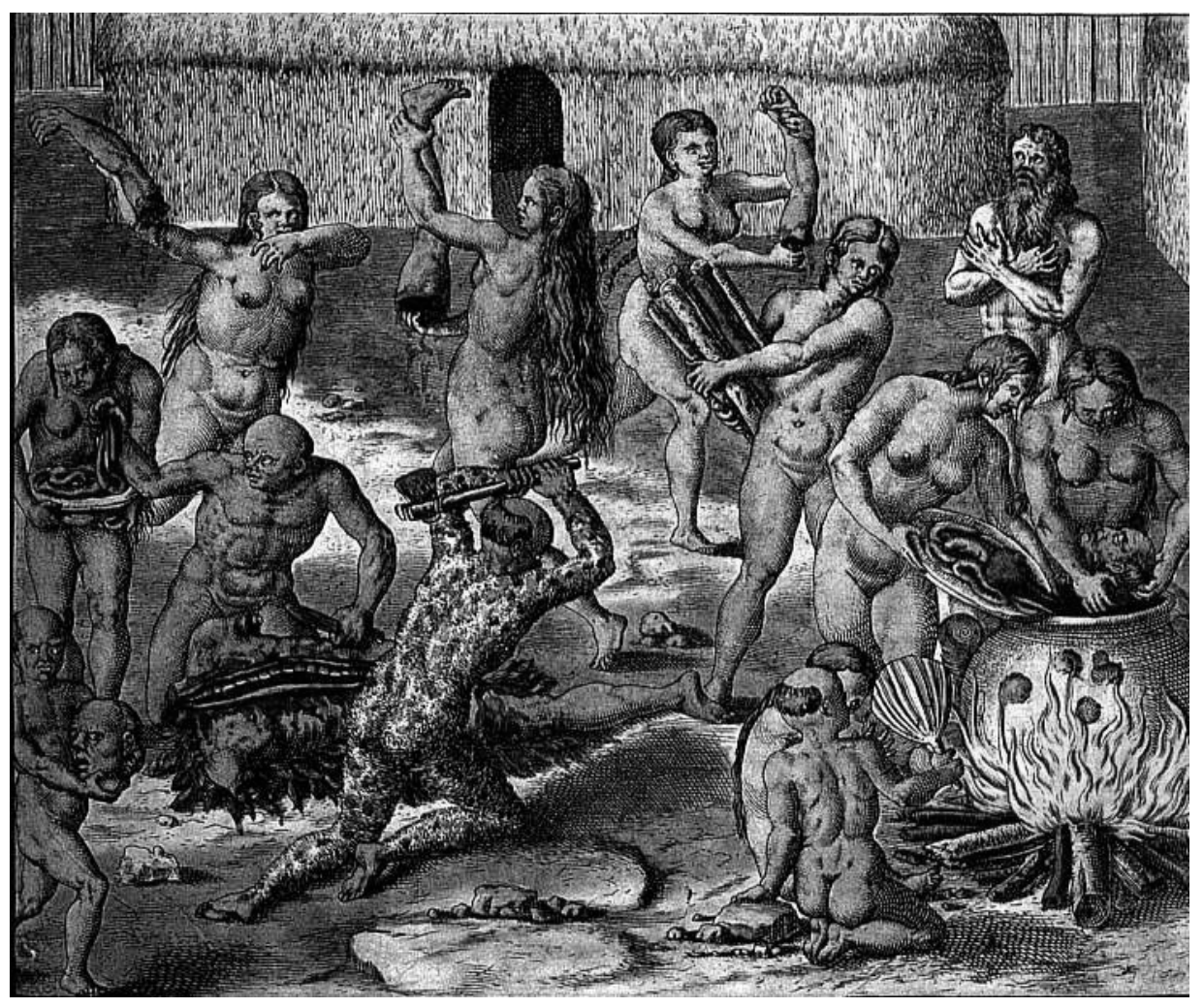

Theodore De Bry, America Tertia Pars (Frankfurt, 1592), 123. Grabado en cobre. 
La descripción del alemán detalla el proceso de desmembramiento y de cocimiento de las vísceras. A pesar de todo, tal vez lo más singular de la escena, tanto en el texto de Staden como en el grabado de De Bry, sea la extraña actitud de alegría de las mujeres, manifiesta con el correr alrededor de las cabañas con los miembros cortados de la víctima. El padre José de Anchieta resalta también este aspecto: "Lo despedazan con grandísimo regocijo, más que todo de las mujeres, las cuales andaban cantando y bailando" ${ }^{, 56}$.

Jean de Léry es más sintético en las informaciones de este proceso de fraccionamiento: "Luego después el dueño de la víctima y algunos ayudantes abren el cuerpo y lo despresan" ${ }^{\text {} 57}$. Claude d'Abbeville es más preciso en los pasos seguidos para la preparación del cuerpo:

Se aproximan entonces las mujeres, agarran el cadáver y lo lanzan al fuego hasta que se queman todos los pelos. Lo retiran entonces y lo lavan con agua caliente. Después de estar bien limpio y calvo, le abren el vientre y retiran las entrañas. Lo cortan enseguida en pedazos y lo ahúman o lo asan ${ }^{58}$.

Otros grabados hechos por De Bry para la America Tertia Pars sobre episodios de fraccionamiento del cuerpo de la víctima para el festín coinciden en todos los casos con las narrativas de Staden y Léry, al indicar que esta función era realizada específicamente por hombres. En el grabado, se puede destacar la presencia de una pequeña hacha en la mano de un indio para desmembrar el cuerpo del sacrificado. Jean de Léry se refiere a la presencia de esta herramienta entre los tupinambás:

Después de la llegada de los cristianos a ese país, comenzaron los salvajes a cortar y tasajear el cuerpo de los prisioneros, animales y otras presas con hachas $\mathrm{y}$ herramientas dadas por los extranjeros, lo que hacían antes con piedras afiladas, como me fue dicho por un anciano ${ }^{59}$.

El hacha de metal es un elemento ajeno al contexto tupinambá, por lo menos en los primeros tiempos; solo con el contacto con portugueses y franceses los indios comenzaron a obtener herramientas en metal ${ }^{60}$. Las imágenes del fraccionamiento

\footnotetext{
${ }^{56}$ José Anchieta, Cartas: informações, fragmentos históricos e sermões (Belo Horizonte y São Paulo: Itatiaia; Universidade de São Paulo, 1988), 226. TE.

${ }^{57}$ Léry, Viagem, 198.

${ }^{58}$ D’Abbeville, História, 233. TE.

${ }^{59}$ Léry, Viagem, 199. TE.

${ }^{60}$ Sobre estos intercambios, fray Vicente do Salvador escribió: "Os que podem cativar na guerra levam para vender os brancos, os quais lhe compram por um machado ou foice cada um”. História do Brasil 1500-1527 (São Paulo: Melhoramentos, 1965), 95. Pero no eran solo hachas; Serafim Leite comenta que los tamoios recibieron herramientas, espadas y arcabuces de los franceses para combatir a los portugueses.
} 
del cuerpo con un hacha recorren toda la iconografía de la antropofagia ${ }^{61}$. El hacha ya aparece en las primeras imágenes de la antropofagia del Nuevo Mundo y sus habitantes: en la edición de la Lettera de Vespuccio de 1509, en las carnicerías de cinocéfalos de Lorenz Fries, en los caníbales de Münster, en los xilograbados de descuartizamiento y consumo de Las Singularidades de la Francia Antártica. (1557), de Thevet, y aun en varios grabados de Theodoro De Bry de la America Tertia Pars y de la Brevis Narratio.

Los dos últimos grabados muestran la preparación y consumo de la víctima del sacrificio: costillas, piernas y brazos son asados, mientras que otras partes, como vísceras, son cocinadas. Las imágenes aterradoras y macabras muestran cómo todos los tupinambás participan del festín: jóvenes y viejos, hombres, mujeres y niños. El grabado sobre el consumo de las vísceras revela una escena formada por nueve voluptuosas mujeres sentadas en círculo, junto con sus hijos: tres niñas y seis niños que se alimentan de la papilla hecha con tripas de ser humano, ya que los músculos eran destinados a los guerreros de la tribu (Figura 4). Si la escena no tuviera la cabeza desprendida en un plato y las vísceras en otro, recordaría un episodio cotidiano y familiar, aunque la presencia de la cabeza confiere un carácter aterrador y siniestro al grabado.

61 Frank Lestringant, "L'automne des cannibales ou les outils de la conquête", en L'Amérique de Théodore De Bry. Une collection de voyages protestante du XVIe siècle, dir. Michèle Duchet (París: Centre National de la Recherche Scientifique, 1987), 69-104. 
Figura 4

Mujeres y niños de la tribu toman papilla hecha con las tripas del prisionero sacrificado

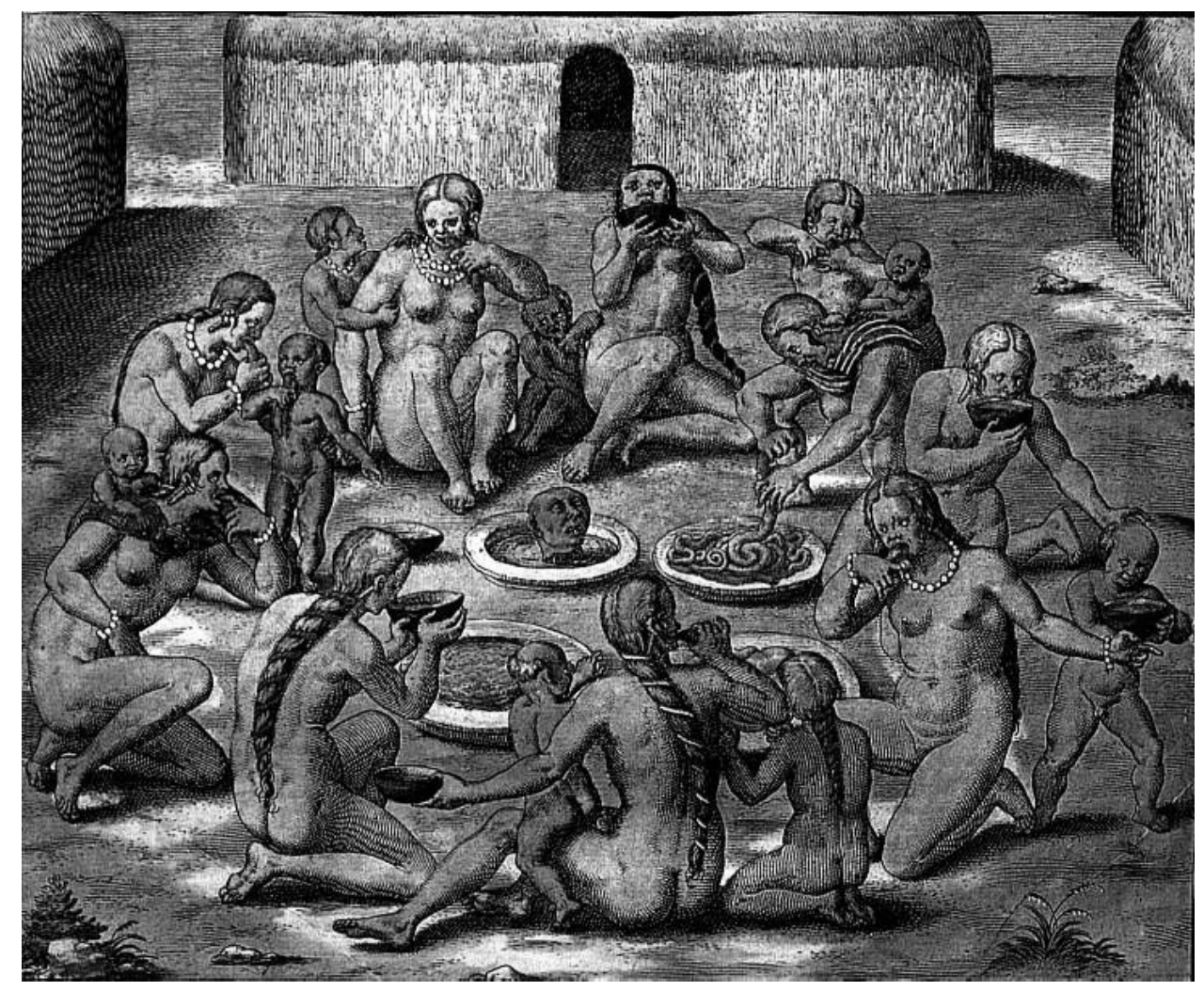

Theodore De Bry, America Tertia Pars (Frankfurt, 1592), 124. Grabado en cobre. 
De Bry basó esta imagen en otra anterior, hecha para la edición ilustrada de la narrativa de viaje de Hans Staden, en 1557. En el xilograbado original no aparece la cabeza del difunto en el plato, esta adición pertenece a De Bry y fue inspirada en los xilograbados con cabezas tajadas de las narrativas de Thevet.

Sobre el consumo de las vísceras por mujeres y niños, Hans Staden, en el Viaje al Brasil, dice que lo siguiente: "Las mujeres guardan los intestinos, los cocinan y del caldo hacen una sopa que se llama mingau, que ellas y los niños beben, comen los intestinos y también la carne de la cabeza; los sesos, la lengua y lo demás que haya será para los niños" ${ }^{\prime 2}$. Thevet también coincide en esta cuestión: "generalmente las mujeres comen las entrañas" ${ }^{\text {,63. }}$.

La última imagen relacionada con el festín muestra carne humana asada en el moquém $^{64}$ y devorada por los indios y es también una de las imágenes más macabras e impresionantes de la America Tertia Pars. El grabado muestra detalladamente miembros fraccionados de varios cuerpos de víctimas puestos a asar en el moquém (Figura 5). Los tupinambá están en el medio del banquete: hombres, mujeres y niños, todos degustando partes de este festín: mujeres viejas lamen sus dedos para no perder nada del terrible manjar y hasta un niño chupa una mano cortada, mientras en el plano de fondo un Hans Staden asustado parece cuestionar las acciones de los indios. Léry señala que: "Todas las partes del cuerpo, inclusive las tripas, después de ser bien lavadas, son colocadas al humo, en torno al cual las mujeres, principalmente las golosas viejas, se reúnen para recoger la grasa que escurre por las varas de esas grandes y altas parrillas de madera" ${ }^{, 65}$.

En lo que respecta al uso de grasa y consumo de sangre por parte de las índias, el padre Anchieta, en una carta de 1565 al general Diogo Lainez, describe que: "Otras se untaban las manos con la grasa y andaban untando las caras y bocas de las otras, y tal había que cogía la sangre con las manos y la lamía, espectáculo abominable, de manera que tuvieron una buena carnicería con que hartarse"66.

En el grabado de De Bry, a diferencia de lo informado en el relato de Staden, no aparecen tripas asadas. Claude D’Abbeville, en la Historia de la Misión de los

\footnotetext{
${ }^{62}$ Staden, Viagem, 189-191. TE.

${ }^{63}$ Thevet, As Singularidades, 132.

64 "Para isso usam uma espécie de grelha de madeira a que dão o nome de bucam, moquém. Essa grelha é formada de quatro forquilhas de madeira, de grossura de uma perna, fincadas no chão em forma de quadrado ou retângulo e sôbre as quais se colocam duas varas com outras menores atravessadas e próximas umas das outras. O moquém ergue-se cêrca de tres pés acima do chão e tem comprimento e largura proporcionais ao número de homens que devem ser moqueados, não raro incrivelmente grande". D’Abbeville, História, 233.

${ }^{65}$ Léry, Viagem, 199. TE.

${ }^{66}$ Anchieta, Cartas, 226. TE.
} 
Padres Capuchinhos, hace una descripción muy próxima de la imagen del grabado de De Bry:

Encienden fuego debajo de la parrilla sobre la cual colocan todos los pedazos del pobre cuerpo descuartizado: cabeza, tronco, brazos y costillas, sin olvidar piernas, manos, pies, inclusive entrañas o parte de ellas, dejando el resto para el caldo. Nada pierden, en suma, y tienen cuidado de voltear constantemente los pedazos para asarlos bien; y aprovechan además la grasa que escurre por las varas y lamen la que se coagula en las horquillas. Todo bien cocido y asado, comen los bárbaros esa carne humana con increíble apetito ${ }^{67}$.

${ }^{67}$ D’Abbeville, História, 233. TE. 
Figura 5

Preparación de la carne humana en el moquém

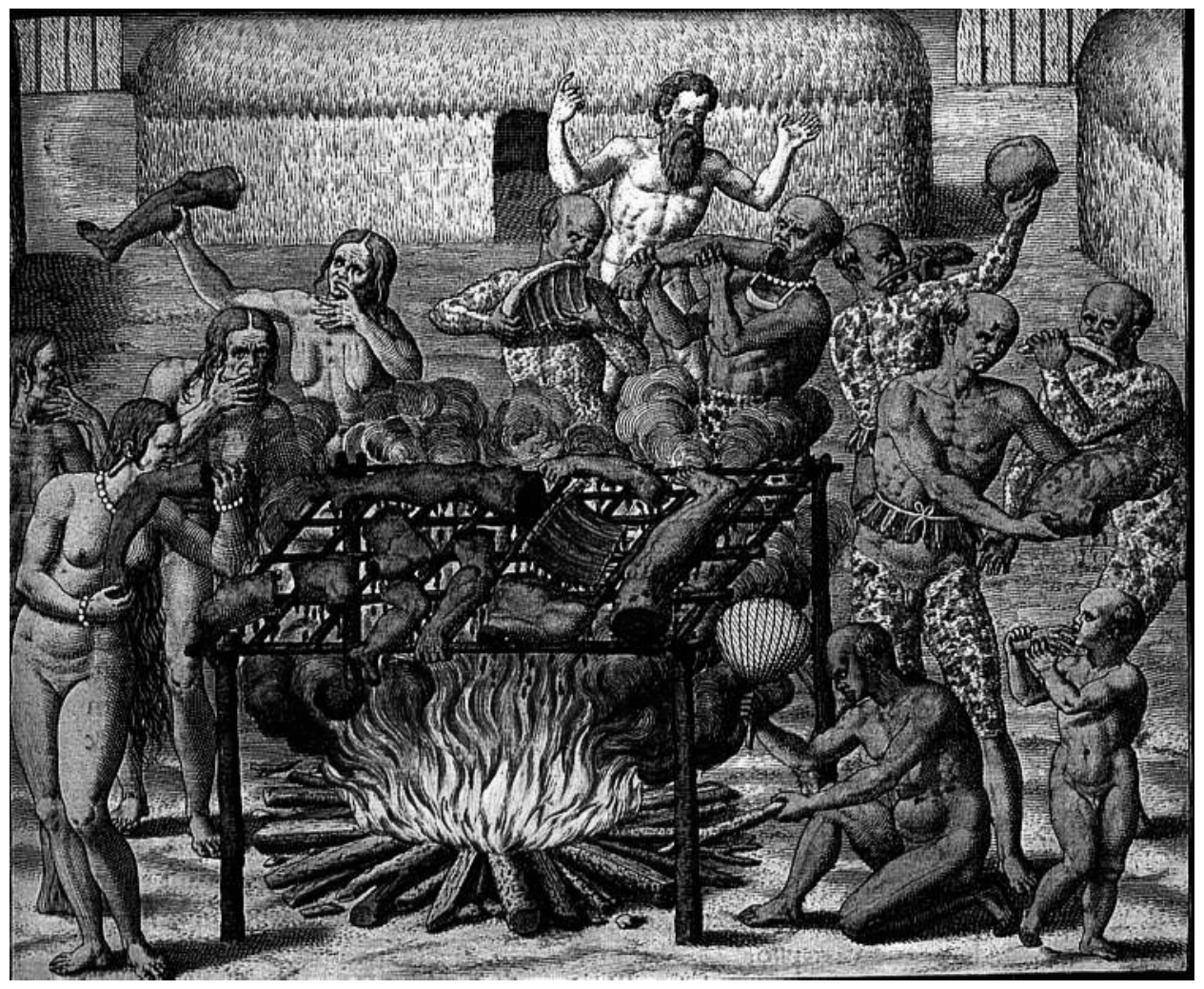

Theodore De Bry, America Tertia Pars (Frankfurt, 1592), 125. Grabado en cobre. 
Sobre lo poco que se sabe de la distribución de las partes del cuerpo de la víctima, Florestan Fernández aclara que:

Los actos canibalísticos no se limitaban a un sector social determinado, a la comunidad de los guerreros o de los ancianos: eran colectivos, y participaban de ellos, de una manera o de otra, niños y adultos, hombres y mujeres. Los niños, los jóvenes de ambos sexos y las mujeres en general tomaban parte del banquete colectivo a través de la ingestión del mingau, hecho con el intestino y con otros órganos de la víctuma. Los hombres adultos, es decir, los avá y tujuaé, devoraban las demás partes del cuerpo después de ahumadas ${ }^{68}$.

Así, que la india coma un brazo contradice las informaciones dadas por Thevet y Staden, en las cuales las mujeres consumían las vísceras y no los miembros y músculos (brazos o piernas), que eran reservados a los guerreros ${ }^{69}$. Las indias del festín contradirían el grabado anterior que muestra mujeres y niños consumiendo la papilla hecha con las vísceras e intestinos.

El grabado sobre la preparación de la carne humana en el moquém de la Americx Tertia Pars, en el cual hombres y mujeres tupinambá devoran un cuerpo cortado, arroja varias dudas con relación al número de indios que participaba de estos rituales y de la cantidad de carne humana consumida. Si creemos en el grabado de De Bry, once tupinambás, cuatro mujeres, seis hombres y un niño, estarían devorando las partes humanas de por lo menos tres prisioneros. Esto puede comprobarse al contar los brazos fraccionados: la india joven muerde uno; el guerrero que tiene un collar devora el segundo; otros dos brazos están siendo asados en la barbacoa, mientras el niño chupa los dedos de una mano; para un total de cinco manos, lo que daría tres víctimas para alimentar once tupinambás. Léry registra millares participado: "Todas las aldeas circunvecinas son avisadas del día de la ejecución y pronto comienzan a llegar de todos lados (...) allí se reúnen en torno de él, algunas veces en número de tres a cuatro mil’,70. Fray Vicente del Salvador dice que: "entonces ordenan grandes fiestas y juntas de parientes y amigos llamados desde treinta y cuarenta leguas" ${ }^{\text {"71. }}$.

De ese modo, ¿cuántas víctimas tendrían que ser sacrificadas para que todos fueran alimentados? Hans Staden ${ }^{72}$ y Gabriel Soares de Souza ${ }^{73}$ también indican que algunas partes eran guardadas para ser consumidas después. Esto indica que la

\footnotetext{
${ }^{68}$ Florestan Fernandes, A Função social da Guerra na Sociedade Tupinambá (São Paulo: Universidade de São Paulo, 1970), 296. TE.

${ }^{69}$ Raminelli, Imagens, 97.

${ }^{70}$ Léry, Viagem, 193, 194.

${ }^{71}$ Salvador, História, 95.

${ }^{72}$ Staden, Viagem, 191.

${ }^{73}$ Souza, Tratado, 251.
} 
carne aun sobraba. Con certeza, la imagen del grabado de Theodoro De Bry no puede ser tomada de forma literal. Entre tanto, Jean de Léry confirma que a veces era necesario más de un prisionero para las ceremonias:

En cuanto a la carne del prisionero, o de los prisioneros, porque a veces matan dos o tres en un solo día (...) todos los que asisten al fúnebre sacrificio se reúnen en torno a las hogueras, contemplándolos con feroces miradas, y por grande que sea el número de los convidados, ninguno sale de allí sin su pedazo ${ }^{74}$.

Theodoro De Bry tendría en cuenta las indicaciones de Léry para componer los rostros feroces de los indios de los grabados, específicamente cuando los tupinambás están devorando carne humana. La necesidad de repartir parte de la víctima entre muchos comensales justificaría, por un lado, el sacrificio de más de un prisionero y, por otro lado, la razón de consumir el cuerpo en su totalidad "asado y cocido y completamente devorado" ${ }^{\text {" }}$.

Pero la duda continúa: ¿cómo consigue el cuerpo de una o dos víctimas rendir para alimentar la población de varias aldeas que se reúnen para el ritual antropofágico? El padre Vasconcellos, en la Crónica de la Compañía de Jesús, explica cómo los indios consumían una víctima de manera que alcanzara para todos:

Entra el principal Almotacel a repartir la carne del difunto. A esta la manda dividir en tantas partes [de forma] que todos puedan alcanzar un poco de la cocción (...) como es imposible que lleguen a probar mil almas de la carne de un solo cuerpo, se coce muchas veces un solo dedo de la mano, o del pie, en un gran asado, hasta ser bien diluido y después se reparte el caldo en tan pequeña cantidad a cada uno, de manera que pueda decir verdaderamente que bebió por lo menos del caldo donde fue cocida aquella parte de su contrario ${ }^{76}$.

Fray Vicente Salvador también coincide con la información de Vasconcellos: "del caldo hacen grandes recipientes de migajas y papillas de harina de carimã , para suplir la falta de carne y poder llegar a todos" ${ }^{, 77}$. Sobre la preparación del caldo para alimentar a gran cantidad de indios, Métraux especifica que:

Cuando el número de convidados era tan considerable que no permitía la distribución, a cada uno, de parte de la carne, los indígenas cocían el pie, las manos, o también un dedo del cadáver en una olla, y todos podían, entonces, probar el caldo. Si había, por el contrario, abundancia de carne, el excedente del banquete era preparado y guardado en espera de otro festín. Los huéspedes llevaban a casa pedazos de carte y, apenas llegaban a la aldea, organizaban una nueva borrachera

\footnotetext{
${ }^{74}$ Léry, Viagem, 199-200. TE.

${ }^{75}$ Gândavo, A primeira, 160.

${ }^{76}$ Vasconcellos, Chronica, Libro 1, 56. TE.

${ }^{77}$ Salvador, História, 96.
} 
para concluir el banquete. Si el jefe de la aldea estaba ausente, no olvidaban los indios de guardarle su parte ${ }^{78}$.

Este grabado de la preparación de los miembros en el moquém, junto con el de las mujeres que raspan la piel del prisionero, sigue las descripciones de las narrativas de Staden y Léry, pero no sus estampas. Estos dos grabados permiten percibir elementos originales propios de Theodoro De Bry y en este último grabado el flamenco se toma más libertades y se distancia de las informaciones dadas por los cronistas. Si en los otros grabados de la Americæ Tertia Pars De Bry registra la presencia de un ritual mágico-religioso, la estampa de la preparación de la carne humana en el moquém está relacionada con la idea del banquete caníbal, o sea, los indios consumen carne humana por puro placer gastronómico: los tupinambás muerden con avidez brazos y piernas, un niño consume una mano y las viejas indias chupan la sangre y la grasa untada en sus propios dedos.

La imagen del banquete que Theodoro De Bry hace para la Americæ Tertia Pars extrapola los esquemas rituales, aproximándose a las imágenes de las cocinas caníbales de Holbein, Münster y Fries. Una estampa en especial inspirará y marcará profundamente los grabados de De Bry sobre la preparación y consumo del cuerpo: la del Descuartizamiento y consumo de la víctima hecha para la edición de 1557 de la obra Singularidades de la Francia Antártica de Thevet (Figura 6). Aquí, dos hombres son desmembrados y sus miembros, cortados con hacha y puestos a asar en una barbacoa. Una mujer agachada retira las vísceras de un cuerpo decapitado, mientras un niño "juega" con una cabeza cortada. Tanto el grabado de Thevet como el de De Bry recurren a la tradición iconográfica sobre antropofagia, como bien lo destaca Frank Lestringant:

Hay varios elementos de fantasía en esta composición de conjunto bastante tradicional: los carniceros nudistas, armados de machetes, y la cabeza en la punta de una lanza que sale de una ventana, presentes en las viñetas gravadas de la Cosmografía Universal de Sébastien Münster, en las cuales los taurocitos, tártaros, caníbales y otros pueblos bárbaros de los confines intercambiaron sus respectivos atributos. Los niños que juegan a la bola con la cabeza del muerto van a inspirar el teatro macabro escenificado por Théodor de Bry ${ }^{79}$.

${ }^{78}$ Métraux, A Religião, 136-137. TE.

${ }^{79}$ Frank Lestringant, O Caníbal: grandeza e decadência (Brasilia: UNB, 1997), 88. TE. 
Figura 6

Descuartizamiento y consumo de la víctima

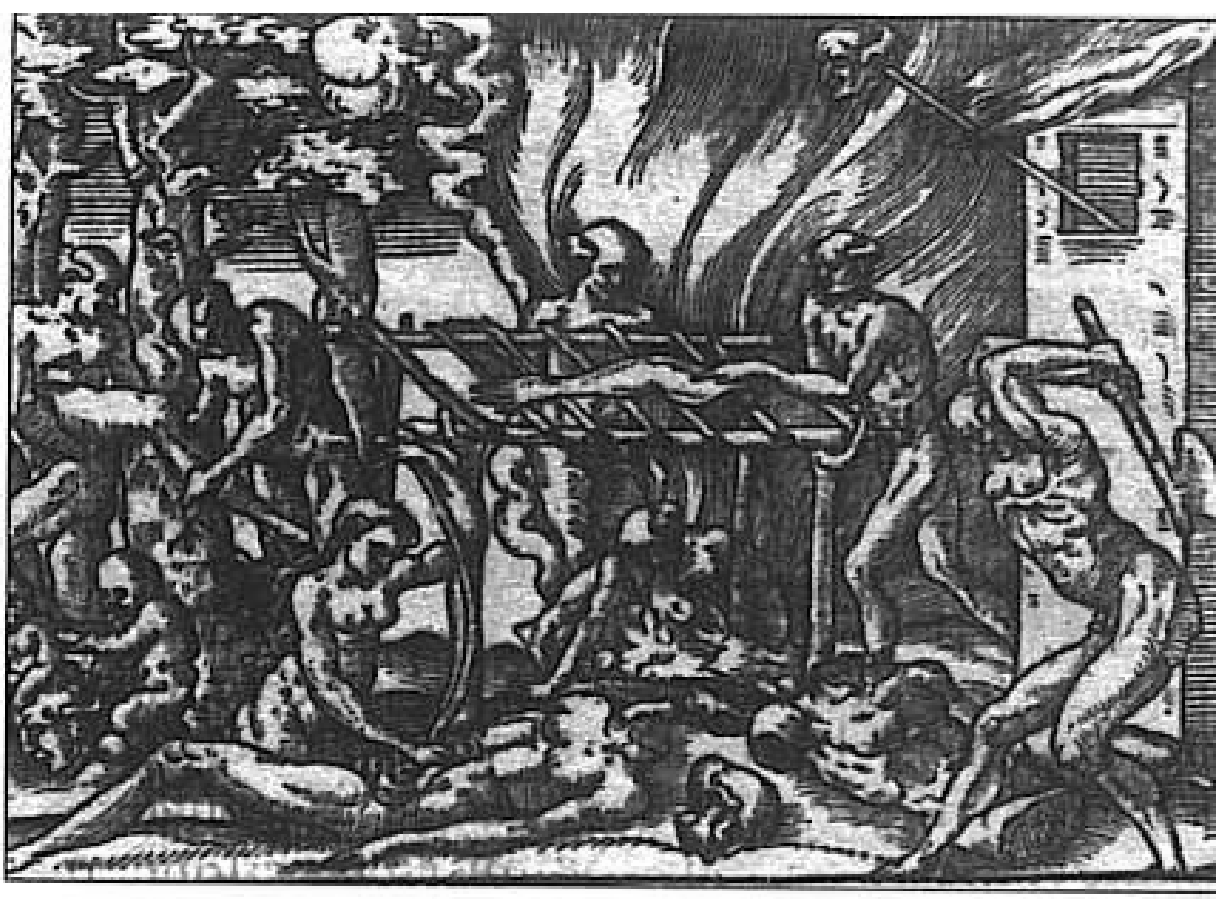

André Thevet, As Singularidades da França Antártica (Belo Horizonte y São Paulo: Livraria Itatiaia; Universidade de São Paulo, 1978), xilograbado (1557). 
En el grabado de la preparación y consumo del cuerpo asado en el moquém, Theodoro de Bry sigue la tradición pictórica de la antropofagia, colocando seres humanos con apariencia monstruosa que devoran miembros humanos, imágenes constantes en las representaciones medievales y en la iconografía de la antropofagia del Nuevo Mundo. Los impresionantes grabados de Theodoro de Bry muestran elementos superficiales del ceremonial de "destrucción" ${ }^{\prime 0}$ del enemigo, un ritual mucho más complejo y amplio, según especialistas como Metraux y Florestan Fernandes. Esa práctica de ingestión de carne humana como venganza formaría parte de un hecho más amplio, que está vinculado a la guerra y que atravieza todos los ámbitos de la sociedad tupinambá. Jean de Léry indicaba que la venganza era la principal razón para devorar al enemigo, un profundo odio y no el placer gastronómico:

Mas no comen la carne, como podríamos pensar, por simple gula, pues aunque confiesan que la carne humana es sabrosísima, su principal intento es causar temor a los vivos. Los mueve la venganza, salvo en el caso de las viejas, como ya observé. Por eso, para satisfacer su sentimiento de odio devoran todo del prisionero, desde los dedos de los piés hasta la nariz y la cabeza, con excepción, sin embargo, de los sesos, los que no tocan ${ }^{81}$.

El padre Simón Vasconcellos en un trecho de la Crónica de la Compañía de Jesus ayuda a comprender cómo el ritual antropofágico era visto por los ojos de los europeos:

Naciones hay de estas que cogiendo a las manos al enemigo, lo atan a un palo colgándolo como se cuelga a una fiera, y lo van tirando y comiendo poco a poco, hasta dejar los huesos limpios, o los cocinan, o los asan, o los dejan al sol sobre piedras (...) o cuando el odio es mayor, comiéndolos crudas, palpitando aún entre los dientes, y escurriéndoles por los labios la sangre del miserable padeciente, cual tigres inhumanos" $" 82$.

Vasconcellos trasmite la idea de que los indios, al practicar el canibalismo, perdían su humanidad, descendiendo al nivel de las bestias o de los monstruos con sus excesos de crueldad. En las imágenes de Theodoro de Bry, el canibalismo es presentado al espectador como verídico, con dos argumentos: por un lado, las escenas están integradas en lo cotidiano y doméstico y, por otro, hay énfasis en los detalles, que dan veracidad a los episodios, no solo por medio de ropas, adornos o artefactos, sino también con los detalles exactos de la forma en que el prisionero es muerto, es decir, el propio ritual ${ }^{83}$. Un elemento que refuerza la veracidad lo

\footnotetext{
${ }^{80}$ Término usado por Fernandes, A função.

${ }^{81}$ Léry, Viagem, 200. TE.

${ }^{82}$ Vasconcellos, Chronica, Libro 1, 132, 53. TE.

${ }^{83}$ Mason, Infelicities, 46-47.
} 
constituye la presencia testimonial de Hans Staden, un europeo sobreviviente de los tupinambá.

En el plano pictórico, la veracidad de los episodios es reforzada por un artificio: la perspectiva usada en los grabados, con una línea del horizonte más alta de la normalmente usada en otras obras de la época, que tenía la función de integrar al espectador como testigo ocular del episodio. Este artificio crea un efecto óptico y parece que la imagen está más cerca de quien la observa; así, no solo Hans Staden sería el único testigo de los episodios, sino, además, el observador del grabado.

\section{Las indias viejas}

En el grabado que muestra la preparación de carne humana, al lado de los indios tupinambá y de la joven india, se destaca la presencia de tres indias viejas y decrépitas. El choque es aún más fuerte para el espectador porque la decadencia física de los cuerpos de las viejas, sus senos flácidos, pieles arrugadas, rostros feos, sin adornos, son más evidentes y acentuados por el contraste con la joven india que está a su lado, de cuerpo voluptuoso, senos firmes, con adornos y postura elegante. En el relato de Hans Staden no existe diferenciación entre las mujeres que participan del ritual antropofágico: "Entonces las mujeres unen los cuatro pedazos y corren alrededor de las cabañas, haciendo una gran gritería (...). Las mujeres guardan los intestinos, los hierven y del caldo hacen una sopa" ${ }^{\text {" }}$. A diferencia de Staden, en el Viaje a la Tierra del Brasil Jean de Léry resalta la presencia de las viejas indias que quedan cerca del moquém, en el cual se asan las carnes de la víctima:

En torno del cual las mujeres, principalmente las golosas viejas, se reúnen para recoger la grasa que escurre por las varas de esas grandes y altas parrillas de madera; y exhortando a los hombres a proceder de manera que ellas tengan siempre tales manjares, se lamen los dedos y dicen: iguatú, que quiere decir "está muy bueno" 85 .

Este texto sería la fuente inspiradora del grabado de Theodoro De Bry, ya que los elementos básicos de la imagen están presentes: parrillas, indios, las viejas golosas que no querrían perder nada de la víctima. De Bry traduce esa referencia textual en la actitud corporal de las indias, es decir, la de chupar los dedos, en tanto el resto de los indios que participan del festín devora la carne de las partes humanas o por lo menos la saborean. Entretanto, las viejas, a pesar de tener partes humanas a su alcance, no aparecen mordiéndolas, sino chupando sus dedos. Una de las viejas en los planos de fondo tiene incluso una pierna en su mano derecha y aun así no la

\footnotetext{
${ }^{84}$ Staden, Viagem, 187 y 190.

${ }^{85}$ Léry, Viagem, 199. TE.
} 
muerde, sino que prefiere chupar el dedo pulgar de su mano izquierda. De Bry, al presentar a las viejas chupando los dedos, estaría haciendo una alusión a la falta de dientes: solo pueden chupar y sorber sangre y grasa y no morder carne ${ }^{86}$, como hace la joven india vecina. En la Historia de la misión de los padres capuchinos, de D'Abbeville, se comenta la gula de los tupinambá: "Los hombres parecen hambrientos como lobos y las mujeres todavía más. En cuanto a las viejas, si pudieran embriagarse de carne humana, gustosamente lo harían" ${ }^{\text {"87. }}$.

La segunda indicación en el texto de Jean de Léry se refiere a la grasa, que en el grabado puede ser notada escurriendo, junto con sangre de las partes fraccionadas de las víctimas en el moquém. Las viejas son descritas de forma negativa en el texto de Léry, y aparecen como golosas en exceso e incitadoras del canibalismo, sin contar con el placer y la agitación frenética que sienten con la matanza: "En seguida, las otras mujeres, sobre todo las viejas, que son más golosas de carne humana y ansían la muerte de los prisioneros, llegan con agua hirviéndo, lavan y desollan el cuerpo, a fin de arrancarle la epidermis" ${ }^{\prime 88}$.

La gula llevaba a las indias al punto de no querer perder nada de la víctima y generarles ansiedad. La descripción detallada hecha por Simón de Vasconcellos en la Crónica de la Compañía de Jesús sobre las indias viejas es bastante apropiada para la imagen del grabado de Theodoro De Bry:

Luego de que el triste preso va saliendo de la cárcel para la muerte, es costumbre ir a recibirlo a la puerta seis o siete viejas más feroces que tigres y más inmundas que arpías, de ordinario tan envejecidas en este oficio como en edad, pasando de cien años, que así las escojen. Van cubiertas con las primeras ropas de nuestros primeros países, pero pintadas todas de un barniz rojo y amarillo, con que se consideran muy agraciadas: van ceñidas por el pescuezo y la cintura, con muchos y cumplidos collares de dientes afilados, que han tomado de las calaveras de los muertos que en semejantes solemnidades han ayudado a comer: y para mayor recreación van ellas cantando y danzando al son de ciertos instrumentos, que llevan en las manos para el efecto de recibir la sangre, juntamente con las entrañas del padeciente ${ }^{89}$.

La descripción de las viejas en la obra de Vasconcellos es similar a la de De Bry, que las graba desnudas, arrugadas, de avanzada edad, lo que no es un impedimento para ser las más dispuestas al sacrificio y al consumo de la víctima. El jesuita aún adiciona la experiencia de las viejas en el canibalismo, comparándolas con las harpías; esta analogía de Vasconcellos con la mitología clásica ayuda a entender la imagen que los padres tenían de las viejas indias y su asociación con el mal.

\footnotetext{
${ }^{86}$ Bucher, Icon and Conquest, 51-53. Raminelli, Imagens, 100.

${ }^{87}$ D'Abbeville, História, 233. TE.

${ }^{88}$ Léry, Viagem, 198. TE.

${ }^{89}$ Vasconcellos, Chronica, Libro 1, 132, 55. TE.
} 
De la misma forma que Léry y Vasconcellos, Gândavo coincide con la idea de la gula vinculada a las viejas; el cronista portugués comenta que las ancianas acostumbraban recoger la masa encefálica: "Está una india vieja lista, con un calabazo grande en la mano y, cuando el padeciente cae, acude muy rápidamente a ponerlo en la cabeza para recoger los sesos y la sangre" ${ }^{\text {" }}$.

La experiencia de las indias viejas en el canibalismo estará asociada a la idea generalizada por algunos cronistas de que eran los más viejos los que participaban, efectivamente, del consumo de carne humana. El gobernador Gabriel Soares de Souza era uno de los que lo afirmaban:

Y los hombres mancebos y mujeres mozas solamente la probaban, y los viejos y las viejas son los que comen mucha de esta carne y guardan alguna de la asada en el moquém como reliquia, para con ella de nuevo tornar a hacer fiestas y guardan alguna carne asada del moquém como reliquias, para con ella de nuevo volver a hacer fiestas, en caso de ocurrir que no maten a otro contrario tan pronto ${ }^{91}$.

El padre Azpilcueta, en una carta del 28 de marzo de 1550, es más específico: "replican algunos que solamente la comen las viejas; otros dicen que sus antepasados comían y que ellas deben comer carne humana",92.

Los relatos no solo tienden a reforzar la imagen negativa de las viejas sino también a aumentar su protagonismo, especialmente en las costumbres antropofágicas. Antonio Pigafetta, en su crónica del viaje de Magallanes, será el primero en sugerir que una india vieja habría dado origen a la monstruosa costumbre del canibalismo entre los indios del Brasil:

Esto de comerse uno al otro fue introducido por una vieja que no tenía sino un hijo, que fue muerto por los enemigos. Algunos días después, los suyos capturaron a uno del grupo que había matado a su hijo y lo condujeron delante de la vieja. Ella, al verle y recordar a su hijo, como una perra enojada le saltó encima y le mordió en la espalda. Este hombre pudo escapar y regresar a los suyos, a quienes dijo que habían intentado comerle, mostrando la huella de los dientes en la espalda. Así que cuando estos últimos capturaron de nuevo a los otros, [se] los comieron, y luego estos a ellos, y así se estableció la costumbre ${ }^{93}$.

${ }^{90}$ Gândavo, A primeira, 160. TE.

${ }^{91}$ Souza, Tratado, 251. TE.

${ }^{92}$ Cartas Avulsas, 1550-1568. Azpilcueta Navarro e Outros (Belo Horizonte y São Paulo: Itatiaia; Universidade de São Paulo, 1988), 77. TE.

${ }_{93}$ Antonio Pigafetta, La primera vuelta al mundo. Las mejores crónicas marinas I (Buenos Aires: Ameghino, 1998), 42-43. Resaltados del autor. 
Según Léry, la expresión de agrado de las viejas -iguatú o Ikatú- al degustar la grasa de la víctima ${ }^{94}$ estaba relacionada con la preferencia que los indios de las tierras del Brasil tenían por el terrible manjar. Al lado del sentimiento de venganza, los cronistas coincidirán en decir que una de las razones de la antropofagia era el gusto por la carne humana, como el padre Vasconcellos escribe:

Porque tenían aquel por el manjar más sabroso, vital y provechoso a la naturaleza humana de cuantos hay en la tierra; no hay carne de fiera, venado, puerco de monte, armadillo, roedor, conejillo, comida suya, tan apreciada, que se aproxime a un solo pedazo de carne humana: viene a ser para ellos el fabuloso néctar de los Dioses (...) el apetito de la gente del Brasil por carne humana. Lo que tengo para mí es que crece en ellos el gran deseo desde pequeños, a medida que tienen que vengarse de sus enemigos: y como es el culmen de la venganza comer las carnes, de aquí viene que a medida que aumenta el gusto por la venganza nace con ellos el de la comida ${ }^{95}$.

Ese gusto por la carne humana hacía de los indios, especialmente de las viejas indias, incorregibles y reincidentes en esta costumbre, que chocaba a los europeos. Es famoso el episodio citado por Simón de Vasconcellos de un padre de la Compañía de Jesús y una vieja india que, aunque convertida al cristianismo y próxima a morir, continuaba pertinaz en su deseo de carne humana ${ }^{96}$ :

Que penetrando una vez en el sertón, llegando a cierta aldea, halló una india viejísima, en lo último de la vida; la catequizó en aquel extremo, le enseñó las cosas de la fe (...) [y] le dice "abuela mía (así llaman a las que son muy viejas), si yo os diera ahora un poco de azúcar u otro bocado reconfortante de allá, de nuestras partes del mar, ¿no comeríais?” Respondió la vieja, catequizada ya: "Nieto mío, no deseo ninguna cosa de la vida, aborrezco ya todo; solo una cosa me podría quitar ahora el aburrimiento: si yo tuviera una manita de un rapaz tapuya de poca edad tiernita y le chupara aquellos huesitos, entonces me parece que podría tomar algún aliento; sin embargo, yo (pobre de mí), no tengo quién me dé uno de estos"97.

${ }^{94}$ Léry, Viagem, 199.

${ }^{95}$ Vasconcellos, Chronica, Libro 1, 49, 32. TE.

${ }^{96}$ Una de las razones argumentadas por el padre João de Azpilcueta Navarro para no darle el bautismo a la gente es la práctica de la antropofagia, que no abandonan ni en el momento de la muerte: "A outra razão, não menos efficaz, de differir o Baptismo é que muito arraigado está nelles o uso de comer carne humana, de sorte que, quando estão em artigo de morte, soem pedil-a, dizendo que outra consolação não levam sinão esta, da vingança de seus inimigos, e quando não lha acham que dar, dizem que se vão o mais desconsolados deste mundo (...) Dizem outros que é o modo usual de vingarem-se, e que os contrarios praticam o mesmo a respeito delles e que eu não deveria arrancar-lhes este seu alimento". Cartas Avulsas, 77.

${ }^{97}$ Vasconcellos, Chronica, Libro 1, 49, 32. TE. 
Las indias viejas y decrépitas encarnan lo que es más temido y odiado en los indios y sus prácticas ${ }^{98}$. En la visión de los cronistas, ellas no solo son las más golosas e incorregibles, sino también las incitadoras del canibalismo. En las narrativas en general, la vieja asume el papel de la venganza, al hostilizar y burlarse del enemigo que será sacrificado, y son vistas por los cronistas como "sádicas", sedientas de sangre y de pura maldad. Con todo, dentro de la comunidad tupinambá, las actitudes de las viejas hacían parte del gran ritual de la venganza contra el enemigo ${ }^{99}$.

\section{La figura de la vieja en la iconografía}

El grabado de la Preparación y consumo de la carne humana asada en el móquem fue el único incluido en la America Tertia Pars que contiene viejas decrépitas. Entre tanto, el editor hugonote había hecho antes un grabado similar en la Admiranda Narratio, sobre Adán y Eva en el Paraíso, donde la serpiente es representada como una figura híbrida ${ }^{100}$, es decir, la mitad superior humana, con senos caídos de mujer vieja, pero con el rostro joven y la parte inferior zoomórfa (Figura 7).

\footnotetext{
98 Jean Delumeau, História do Medo no Ocidente, 1300-1800. Uma cidade sitiada (São Paulo: Companhia das Letras, 1989), 347 y Raminelli, Imagens, 102.

${ }^{99}$ Raminelli destaca dos tipos de venganza: "a masculina, caracterizada pela execução e pelo fracionamento do corpo; e a feminina, expressa na alegria, no prazer e no escárnio". Ronald Raminelli, "Eva Tupinambá", en História das Mulheres no Brasil, ed. Mary del Priore (São Paulo: Contexto; Unesp, 2001), 35.

${ }^{100}$ Véase un interesante análisis de este gravado en el capítulo 3.3, "Adão, Eva e os Pictas nas selvas da Virgínia”, de Baumann, "Thesaurus", 282-330.
} 
Figura 7

Detalle de Eva y la serpiente

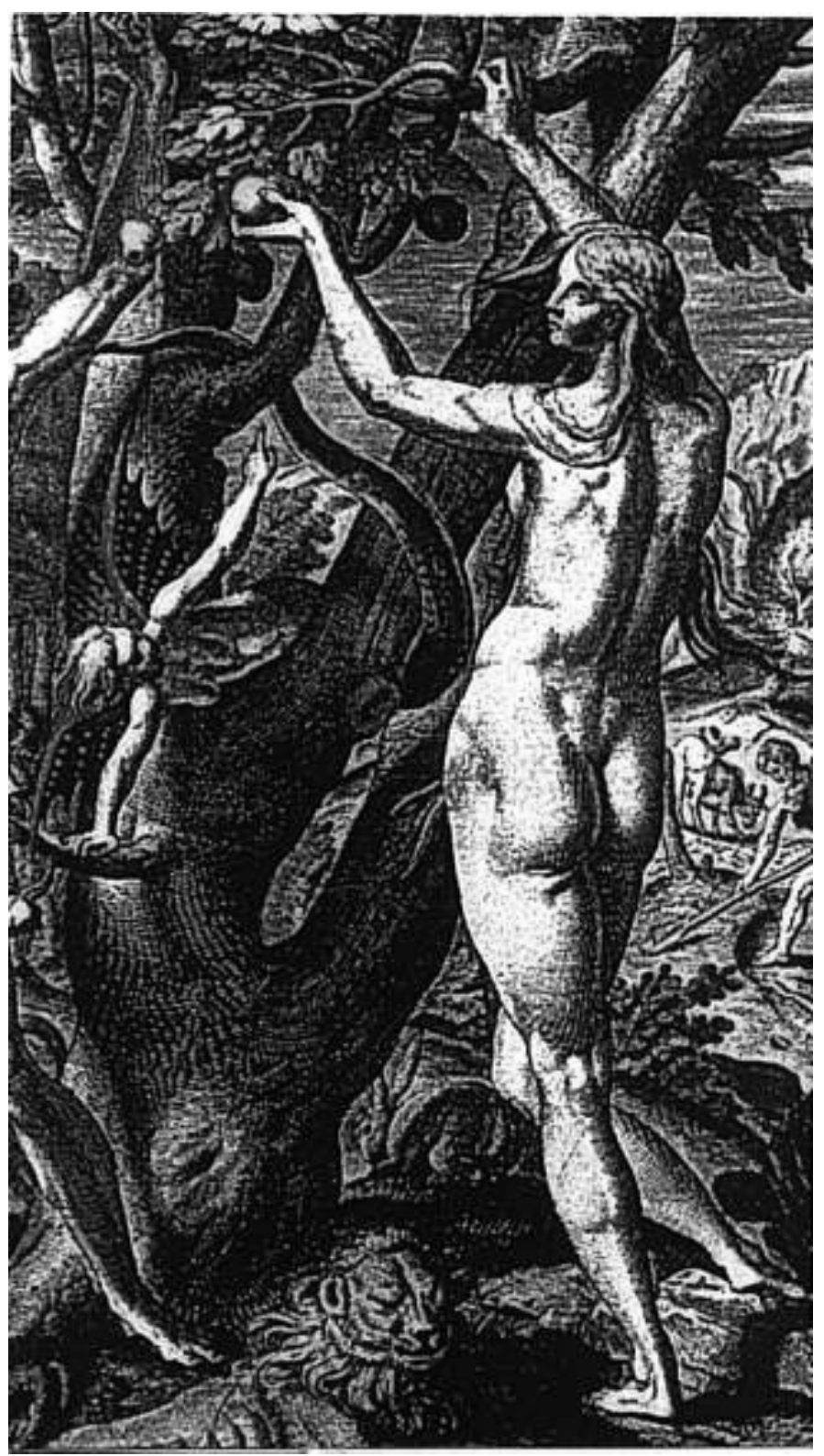

Theodore De Bry, America Narratio (1590), 2. Grabado. 
Posteriormente, Theodoro De Bry elaboró otro grabado con una india caribe vieja y monstruosa en la America Pars Qvarta (1594), volumen dedicado a los viajes de Girolamo Benzoni (Figura 8). El hecho de ser caribe la india y, por lo tanto, practicar canibalismo, la aproxima a las indias viejas tupinambá. El grabado presenta una anciana ${ }^{101}$ de senos caídos, fea, con argollas en las orejas y en la nariz, esposa de un cacique caribe de la provincia de Cumana que trae una cesta de frutas al gobernador Pedro Herrera ${ }^{102}$. La estampa original, en la cual el flamenco basó su imagen, pertenecía a la Historia del Mondo Nuovo, de 1565 (Figura 9).

Este xilograbado es una de las pocas referencias a imágenes de indias viejas hechas antes de Theodoro de Bry, es simple y poco acabada y presenta a una india desnuda, sentada, con el cuerpo pintado y frutas a sus pies y, al lado de ella, tres hombres sentados a la mesa. Uno de los cambios hechos por De Bry en el grabado de tallo dulce fue haber llevado la escena al interior de la casa del gobernador y no afuera, como aparecía en el xilograbado. Por medio de la perspectiva, tanto los personajes como el espectador son integrados al espacio interior de la casa del gobernador. El flamenco presenta simultáneamente el momento anterior, cuando la india se aproxima desde la casa donde estaba Herrera.

\footnotetext{
${ }^{101}$ Sobre la mujer vieja de la provincia de Cumana, véase el capítulo 6, "The Fateful Gift" de Bucher, Icon and Conquest, 65-67.

${ }_{102}$ Michael Alexander, ed., Discovering the New World. Based on the works of Theodore de Bry (Londres: Harper \& Row, s. f.), 127.
} 
Figura 8

India monstruosa de Cumana

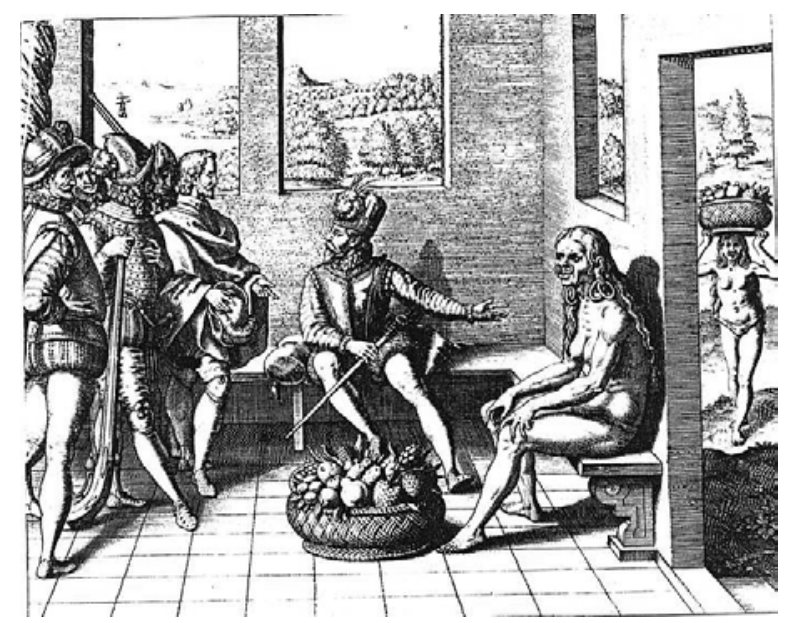

Theodore De Bry, America Pars Qvarta (1594), 153. Grabado.

Figura 9

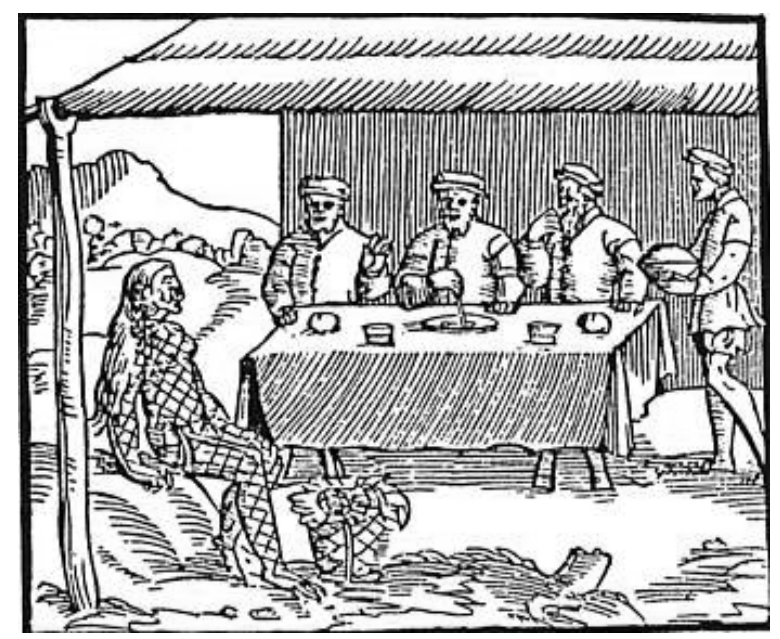

Girolamo Benzoni, Historia del Mondo Nuovo (1565), 8. Xilograbado. 
Las tres imágenes hechas por De Bry -la serpiente de senos pendientes, las viejas indias tupinambá y la india caribe monstruosa de Cumana- estarían asociadas al signo del demonio y del mal, según las interpretaciones de Bouyer y Duviols ${ }^{103}$. Bucher ${ }^{104}$ hace una lectura de estas imágenes como degradación, punición y condenación de los indios del Nuevo Mundo, lectura compartida por Belluzzo ${ }^{105} \mathrm{y}$ Raminelli ${ }^{106}$ en lo que se refiere a las viejas antropófagas tupinambá, mientras que Baumann cree que las formas aberrantes en Theodoro de Bry no significan solo degradación y más bién indican la posibilidad de transformación ${ }^{107}$.

Dando continuidad a los Grandes Viajes de Theodoro De Bry, Matthäus Merian publicó la Decima Tertia Pars, en 1634, colocando en el frontispicio una india de apariencia deformada con enormes senos caídos, parecida a la india de Cumana. El grabado ilustra a una pareja de indios de América del Norte, cuyas deformaciones faciales son profundas, con incrustaciones en el rostro, orejas perforadas y estiradas por el peso de los aretes, con los cuerpos desnudos y la piel pintada. Las figuras principales de la plancha heredaron las características de las criaturas de la teratología, como el excesivo desarrollo de los miembros ${ }^{108}$, en el caso de la india con el tamaño exagerado de las orejas y de los senos caídos.

La iconografía sobre los tupinambá anterior a Theodoro De Bry no trató indias viejas y en las ediciones ilustradas de André Thevet, Jean de Léry y Hans Staden estas tampoco aparecen, si bien en los xilograbados de este último la mujer gana mucha importancia, apareciendo en la mayoría de las estampas. En las representaciones antropofágicas las indias viejas y decrépitas no aparecen. La

103 “C'est un signe diabolique que l'on retrouve dans l'iconographie brésilienne où les vieilles femmes sauvages servent à marquer du signe de Satan l'indienne dévoreuse de chair humaine en la représentant sous la forme traditionnelle de la sorcière en Europe". Marc Bouyer y Jean Paul Duviols, "Les Grands Voyages de Théodore de Bry", en Le Théâtre du Nouveau Monde. Les Grands Voyages de Théodore De Bry, Theodore de Bry (París: Gallimard, 1992), 135.

104 Bernardette Bucher ya había estudiado estas tres imágenes vinculadas con la degradación y decadencia de los indios. Bucher, Icon and conquest, 74-88.

${ }^{105}$ Belluzzo, O Brasil dos Viajantes, 59 y "A lógica das imagens e os habitantes do Novo Mundo", en Índios no Brasil, ed. L. D. B. Grupioni (Brasilia: Ministério da Educação e do Desporto, 1994), 58.

${ }^{106}$ Raminelli, Imagens, 100 y "Eva Tupinambá", 43.

107 Thereza Baumann cree que la lectura de esas imágenes no puede ser considerada como simple degradación sino como transformación: "A androginia, a ambigüidade sexual, o caráter aberrante das formas que aparecem nas imagens de Theodore De Bry pode não significar a inexorável degradação do ser humano nem constituir-se, especificamente, em um estigma do homem americano, mas, ao contrário, significar a esperança da transformação e a possibilidade de escolha do homem". Baumann, "Thesaurus", 321-322.

108 Sobre la hipertrofia de los órganos, véase Claude Kappler, Monstros, demônios e encantamentos no fim da Idade Média (São Paulo: Martins Fontes, 1994), 171-175. 
propia presencia femenina antes de Staden es muy escasa, con excepción de los grabados de las ediciones de las cartas de Vespuccio, que destacan a la mujer, aunque, a pesar de todo, las indias viejas también aquí están ausentes. Extrañamente, porque en las narrativas de viaje de los cronistas franceses, alemanes y portugueses y en las correspondencias de los padres jesuitas, ellas son frecuentemente citadas y, sin embargo, están ausentes en la iconografía sobre los nativos del Nuevo Mundo y sus prácticas caníbales.

Las imágenes de las viejas decrépitas abundan en la iconografía europea del siglo XVI y pueden ser organizadas en tres tipos: las alegorías de las virtudes y los vicios, las edades del hombre y las representaciones de brujas y hechiceras. En el primer tipo, las imágenes de las mujeres viejas como representación de virtudes son muy escasas. Jean Delumeau cita la investigación de S. Matthews-Grieco, que llega a presentar trescientas alegorías del mal por cada alegoría del bien en que aparece la mujer vieja. El contexto neoplatónico da un sustento más lógico a la lectura de los cuerpos degenerados como muestra de vicios:

Que una época que redescubría con deleite la belleza del cuerpo jóven femenino haya sentido repulsión por el espectáculo de la decrepitud no tiene nada de sorprendente. Sin embargo, lo que merece más atención es lo que se escondía detrás del miedo a la mujer vieja y fea. En un tiempo en que el neoplatonismo de moda enseñaba que la belleza era igual a la bondad, se aceptó lógicamente -omitiendo las agotadoras servidumbres de la maternidad- que la decadencia física significaba maldad $^{109}$.

Originalmente, para Platón lo universal era la Idea, algo lejano en un mundo inteligible, de manera que lo real, es decir, la naturaleza, era una imitación, una copia imperfecta de la ella. A su vez, el arte sería una copia de la naturaleza y, por serlo, esta era aún más degradada e imperfecta. En sus Ensayos Montaigne cita que: "Todas las cosas, dice Platón, prodúcelas la naturaleza o el acaso, o el arte. Las más bellas y grandes son frutos de las dos primeras causas; las menores y más imperfectas, de la última" ${ }^{\text {110 }}$. Esa degradación bajo la óptica de Platón le quitaba validez al arte. A partir de estos mismos fundamentos, el neoplatonismo rescataba al artista como un ser especial y diferente del resto de los mortales que, por tener sensibilidad, podría corregir tales fallas de la naturaleza y aproximarse más a la Idea. El artista podría enmendar y corregir las imperfecciones de la naturaleza por ser especial. Ese "don" establecía la función y la misión del artista en el Renacimiento. Por eso, al seguir las ideas del neoplatonismo ${ }^{111}$, los renacentistas

\footnotetext{
${ }^{109}$ Delumeau, História, 348. TE.

${ }^{110}$ Michel de Montaigne, Ensaios (Río de Janeiro, Porto Alegre y São Paulo: Globo, 1961), lib. 1, cap. 31 "Dos canibais", 261.

111 Sobre los orígenes del neoplatonismo en la Antigüedad, consúltese Giovanni Reale y Dario Antiseri, História da Filosofia. Antigüidade e Idade Média (São Paulo: Paulus,
} 
creían que la belleza perfecta no podría ser encontrada en un solo cuerpo y sí dispersa en la naturaleza, en varios individuos, como había sido demostrado en el episodio vivido por el famoso artista griego Zeuxis, que, para hacer su versión de Helena, no escogió una sola mujer, sino que buscó la belleza en varias o, mejor, en cinco vírgenes, como resalta Alberti:

Zeuxis, el más ilustre y competente de todos los pintores (...) no confió imprudentemente en su propio ingenio, como hacen hoy los pintores. Como pensaba que no era posible encontrar en un solo cuerpo toda la belleza que buscaba -cosa que la naturaleza no dio a una sola persona-, escogió las cinco mozas más bellas de toda la juventud de aquella tierra, para de ellas sacar toda la belleza que se aprecia en una mujer ${ }^{112}$.

De acuerdo con los artistas del Renacimiento, la belleza ideal no estaba distanciada del mundo natural y se encontraba dispersa en ella, y el artista, con su sensibilidad e intelecto, tendría la capacidad de reunir y generar la belleza ideal. De este esfuerzo resultaron los famosos cánones. Un cuerpo ideal estaría, en consecuencia, constituido por lo mejor de la naturaleza.

No se aceptaba, entonces, copiar del natural sin ninguna alteración. Las figuras "feas" - que se distanciaban de la belleza idealizada vinculada a la juventud y seguían los modelos clásicos griegos y romanos- comenzaron a representar vicios y faltas. Un cuerpo vigoroso y bello debía ser reflejo del interior virtuoso, por consiguiente, un cuerpo decrépito, degenerado, sería resultado de una vida licenciosa. En una pintura alegórica de Sandro Botticelli de finales del siglo XV, La Verdad desnuda triunfa sobre la Calumnia, presenta a la Verdad como una mujer joven, altiva, elegante, de cabellos largos, coquette, con su brazo derecho extendido en dirección al cielo y desnuda. A su lado, la Calumnia, es representada como una mujer vieja que no muestra su rostro completamente y cubre todo su cuerpo con ropas oscuras; frente al triunfo de la Verdad, la Calumnia se agacha rastrera, y parece intentar huir. Las primeras representaciones de la Verdad desnuda ya se encuentran en $1350^{113}$.

Las dos figuras femeninas establecen un contraste a partir de sus posturas; la joven mantiene una posición corporal más altiva e imponente, con el dedo indicador apuntando al cielo, mientras la vieja parece estar contraída y marchita. Sobre la relación cuerpo y alma, Leon Battista Alberti afirma en su tratado Da Pintura, de 1435:

1990), 1:338-355. Sobre el neoplatonismo en los siglos XV-XVI, véase el vol. 2, "Do humanismo a Kant".

${ }^{112}$ Leon Battista Alberti, Da Pintura (Campinas: Unicamp, 1989), lib. 2, 56, 133. TE.

${ }^{113}$ Erwin Panofsky, Estudios de iconología (Madrid: Alianza Universidad, 1998), 215. 
Existen algunos movimientos del alma llamados afectos, como la ira, el dolor, la alegría y el miedo, el deseo y otros semejantes. Existen también los movimientos de los cuerpos. Los cuerpos se mueven de varias maneras: creciendo, decreciendo, adoleciendo, sanando, cambiando de un lugar a otro. Nosotros, pintores, sin embargo, queremos mostrar los movimientos del alma por medio de los movimientos de los miembros ${ }^{114}$.

Según Alberti, el alma estaría reflejada en el cuerpo y en sus movimientos. Por lo tanto, el cuerpo sería el espejo del alma, premisa que los artistas renacentistas intentaron llevar adelante, sugiriendo en las obras pictóricas, por medio de los movimientos y las posturas del cuerpo, las inclinaciones del alma. En 1507, Albrecht Durero (1471-1528) pintó en la parte posterior de un retrato de un joven, una mujer vieja, delgada, sin dientes, con cabellos grises como en hilachas, arrugada, con un seno colgando fuera de su vestido y sosteniendo con sus manos una bolsa llena de monedas de oro, en una alegoría de la Avaricia. La imagen de la vieja pintada por Durero no es muy diferente de las viejas indias de De Bry: senos caídos, sin dientes, cabello despeinado y feo. La pintura acentúa el estado de decadencia de la mujer vieja y su representación alegórica como vicio y pecado (Figura 10).

Con las persecuciones religiosas, la mujer vieja se reafirma como un emblema de los vicios. Etienne Delaune, maestro de Theodoro De Bry, hizo algunos grabados sobre alegorías del Hambre y de la Envidia, en 1575 (Figura 11). La misma vieja antropófaga de senos suspensos, flaca, con un cadáver a sus pies, devora partes de un niño. La imagen de la vieja que come miembros de un infante hace referencia a un episodio macabro del cerco de Sancerre, del cual fue testigo Jean de Léry, donde el hambre llevó a una pareja a comer su propio hijo de tres años, aconsejados por una vieja ${ }^{115}$. El canibalismo era algo abominable para el europeo cristiano, pero relativamente aceptado cuando eran los salvajes los que cometían este acto. De ese modo, era considerado un pecado mortal, relacionado con el pecado capital de la Gula ${ }^{116}$, llevado a su peor extremo.

\footnotetext{
${ }^{114}$ Alberti, Da Pintura, lib. 2, 43, 116. TE.

${ }^{115}$ Lestringant, $O$ Canibal, 112-114.

${ }^{116}$ Así lo señalan Raminelli, Imagens, 100 y Bucher, Icon and Conquest, 50.
} 
Figura 10

La Avaricia

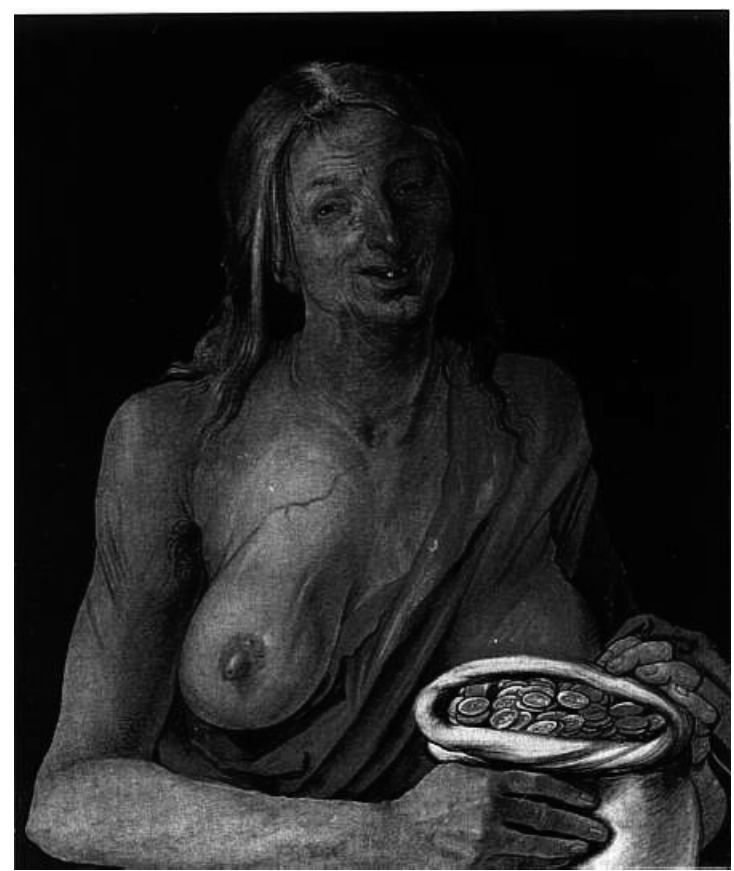

Albrecht Durero. Óleo sobre madera, 35 x 29 cm, Kunsthistorisches Museum, Viena, 1507.

Figura 11

Alegorías del Hambre y la Envidia

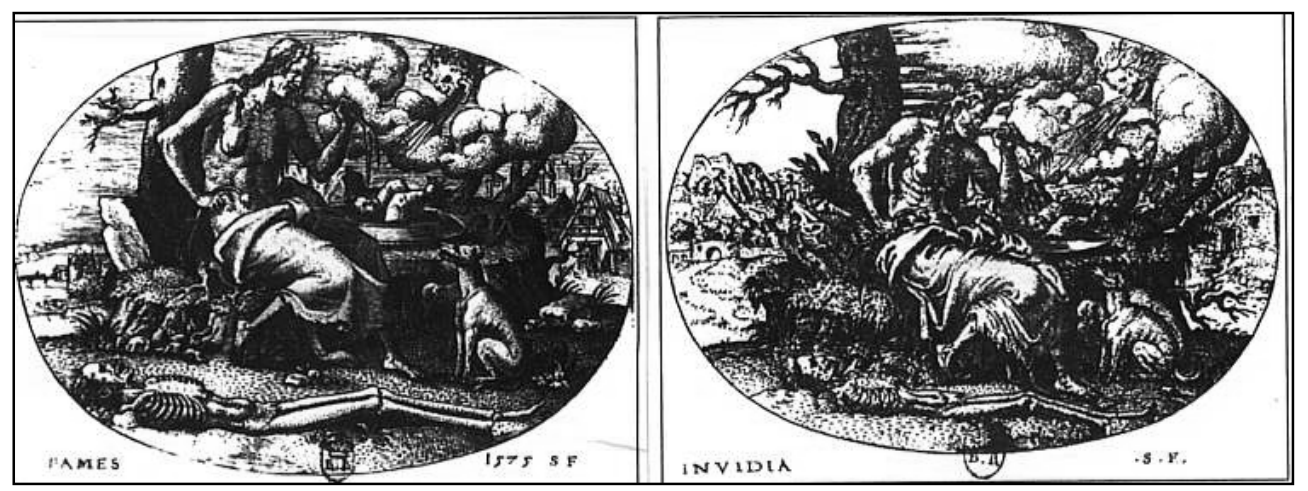

Etienne Delaune. Buril, 1575. 
El segundo tipo de obras que destaca la presencia de las mujeres viejas son las pinturas de las tres edades, que tuvieron mucha difusión al final de la Edad Media y estaban vinculadas a la Danse Macabre ${ }^{117}$. La muerte llega igualmente para todos: pobres, ricos, nobles, religiosos, reyes y gente común ${ }^{118}$. Las pinturas de las tres edades mantendrán ese sentimiento de no poder escapar de la muerte y además incorporarán otros ingredientes, como las marcas del paso del tiempo irreversible en el cuerpo humano, la belleza y la juventud. La única certeza que se puede esperar es la vejez y la decrepitud. La vida en este tipo de pintura es presentada como algo efímero.

Hans Baldung (1484-1545) será uno de esos artistas que harán varias pinturas sobre la temática en cuestión. Discípulo de Durero, heredó ese gusto por lo extraño y por lo misterioso. Baldung es un artista que combina la belleza y la sensualidad de las mujeres jóvenes con la decrepitud y lo macabro de la muerte. Vida y muerte son parte de una misma esencia. Son comunes en este artista las pinturas de mujeres jóvenes, bellas y voluptuosas que son asediadas por la muerte. Algunas veces es apenas su proximidad, en otras, la muerte sujeta violentamente a las doncellas por los cabellos, las abraza, las toca y las besa. Las pinturas de Baldung tienen un marcado tono erótico y macabro; juntan los cuerpos jóvenes $\mathrm{y}$ voluptuosos, llenos de vida, de las mujeres, con la piel arrugada, seca y pútrida de la muerte.

En las Tres edades y la muerte (Figura 12), óleo de Baldung (1539), aparecen cuatro figuras que son una alegoría de las tres edades de la mujer. La muerte está representada como un esqueleto de piel seca, aún pegada a los huesos ${ }^{119}$; en la mano derecha sostiene un reloj de arena o ampolleta, símbolo del paso inexorable del tiempo y del fin que se aproxima. Del brazo de la muerte aparece una mujer vieja, arrugada, decrépita, de cabellos blancos y desaliñados, delgada y de senos caídos, e intenta arrancar las ropas de la moza joven del lado, que intenta cubrir su desnudez. Es bella, elegante, de piel clara, cabellos rubios, senos firmes. A los pies de estas figuras, una niña de brazos parece dormir en el suelo. Las tres mujeres

\footnotetext{
${ }^{117}$ Para profundizar en el tema, véase el capítulo 2, "Do desprezo do mundo às danças macabras". Jean Delumeau, O Pecado e o Medo. A culpabilização no Ocidente (Séculos XIII-XVII) (Bauru: EDUSC, 2003), 69-159.

${ }^{118} \mathrm{El}$ esqueleto reseco, frecuente en los siglos XVII-XVIII, no pertenece a la iconografía característica de los siglos XIV a XVI, dominada por las imágenes repugnantes de la corrupción del cadáver en descomposición. Philippe Ariès, $O$ Homem Perante a Morte (Mem Martins: Publicações Europa-America, 1988), 133.

${ }^{119}$ Las etapas de la descomposición del cuerpo eran tres: en la primera, se mantiene el rostro intacto, pero el vientre ya aparece hinchado por los gases; en la segunda, el cuerpo está desfigurado, podrido y aún cubierto de pedazos de carne; finalmente, en la tercera, el cuerpo está reducido al estado de momia. El cadáver semidescompuesto pasará a ser el tipo más frecuente de representación de la muerte: el tránsito. Ibídem, 136.
} 
representan la misma en la infancia, en la juventud y en la vejez. La figura de la muerte parece querer llevarse a la vieja o por lo menos indica que ella no puede escapar de sus garras y que su tiempo está agotado. Contrasta con la aparente tranquilidad de la niña, que semeja dormir en el suelo sin percibir nada. Baldung insistiría en esta temática en varias versiones. 
Figura 12

Las tres edades de la mujer y la muerte

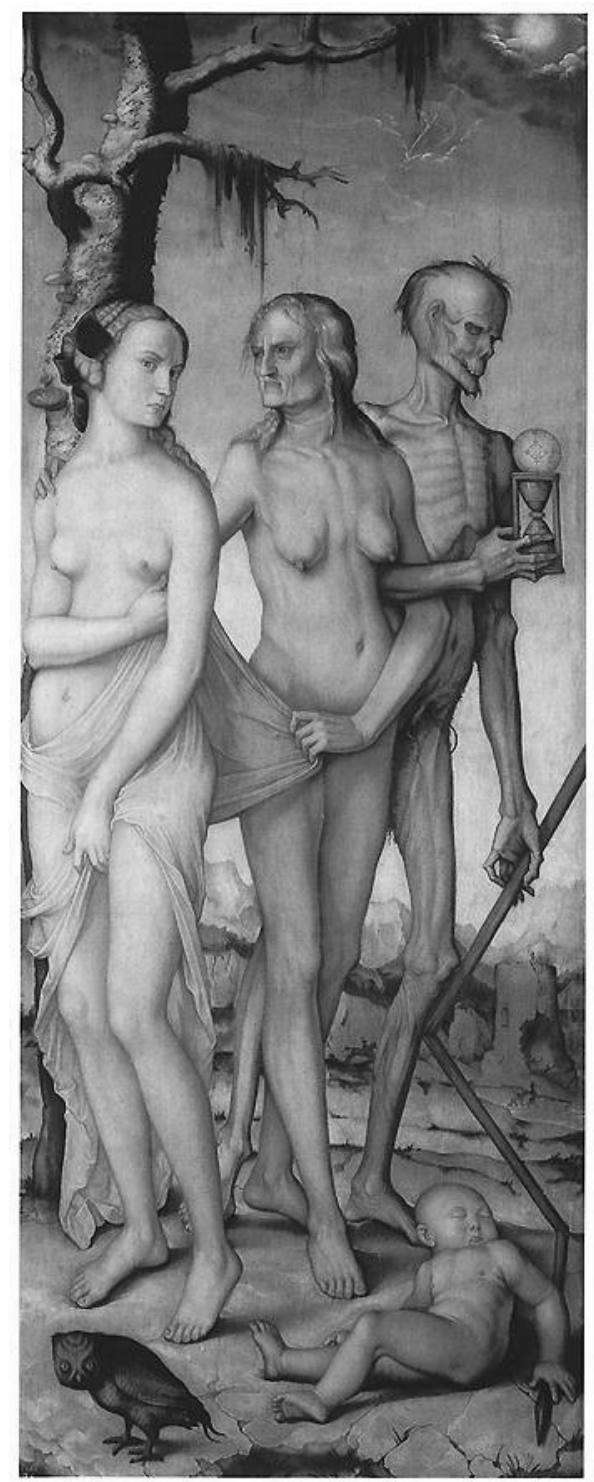

Hans Baldung. Óleo sobre madera, 151 x $61 \mathrm{~cm}, 1539$. 
Las pinturas de las tres edades son una invitación al observador para la contemplación y la reflexión sobre lo efímero de la existencia, el paso inclemente del tiempo en el cuerpo bello y lo banal de las cosas materiales, como bien declamaría décadas después, en el siglo XVII, Francisco Pacheco, en una poesía de sus epístolas:

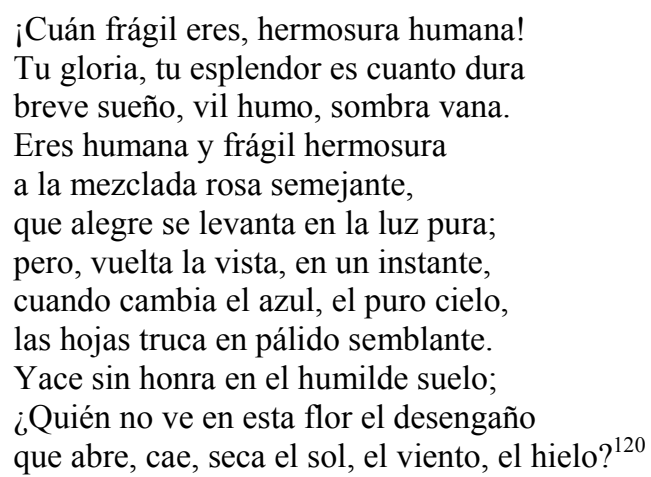

Este tipo de pintura se relaciona con la temática de las Vanitas, al proponer una reflexión similar. Ellas presentan conjuntos de naturalezas muertas, compuestas de objetos extraños: libros, joyas, coronas, copas, relojes (ampolletas), plumas, llaves, algunas frutas secas y casi siempre una calavera o esqueleto (Figura 13). Tales elementos cotidianos poseen en estas pinturas un sentido alegórico: la calavera simboliza la muerte; la copa que ha sido tumbada, la vida que se escapa; el reloj es el tiempo que no para, la vida que siempre está avanzando. Estas pinturas tenían como función llevar al observador a reflexionar sobre la transitoriedad de la vida terrena y lo efímero de las cosas materiales.

${ }^{120}$ Francisco Pacheco, El arte de la pintura (1644; Madrid: Editorial Cátedra, 1990), 370. 
Figura 13

Vanitas

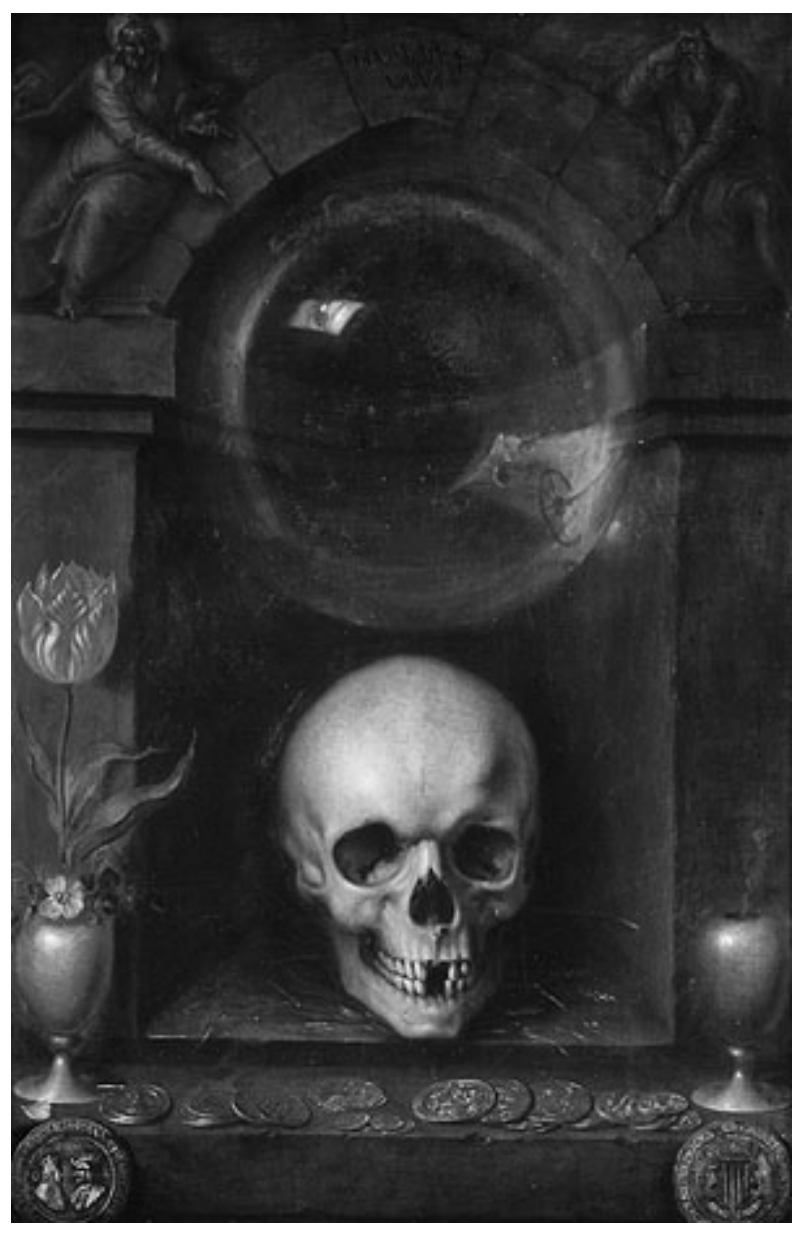

Jacques de Gheyn the Elder (1565-1629). Óleo, 1603. 
El motivo de las Vanitas fue muy difundido en el siglo XVI-XVII; pinturas, normalmente naturalezas muertas, que contenían un sentido emblemático, un sermón sobre la apariencia y la realidad. Inicialmente, estas obras presentaban los placeres de la vida material, apelando al deleite de los sentidos ${ }^{121}$. La religión tendrá una fuerte atracción por estas temáticas. Así, las Vanitas se convierte en un sermón visual y la pintura muestra lo efímero. La vida es corta y lo material pasa, son finitos, mientras que el espíritu es eterno. Los placeres que ella estimula no son reales y sí sola ilusión.

Pero, ¿por qué hacer referencia a las Vanitas?, ¿qué relación guardan con los grabados de De Bry y las mujeres indias? Creo que las indias viejas en el grabado de De Bry deben ser leídas de la misma forma como son leídas las Vanitas y las alegorías de las tres edades, pues ambas invitan a una reflexión sobre lo transitorio y vano de la existencia. La pintura de las Tres edades y la muerte, de Baldung, está muy próxima a la imagen de las viejas representada por el flamenco. Efectivamente, la india joven y las tres indias viejas están vinculadas mostrando lo que el futuro guarda a la bella y voraz india: la corrupción de su cuerpo, el envejecimiento. Entre tanto, De Bry va más lejos del discurso de Baldung en las Tres edades de la mujer; no es solo el implacable pasar del tiempo o la decadencia de la juventud y de la belleza, sino que la corrupción y la degeneración del cuerpo son causadas por el vicio de la práctica antropofágica (figura 14).

El tercer grupo de imágenes que destaca mujeres viejas incluye las obras dedicadas a la temática de la brujería, muy difundidas en los siglos XV-XVII. Entre los artistas más famosos por sus grabados de brujas están Baldung, Durero, Abraham Saur's y Gerald D'Euphrates. En esas estampas aparecen mujeres viejas, de senos pendientes, piel arrugada y rostros grotescos, alternando con brujas más jóvenes, todas desnudas, normalmente en episodios de Sabbat, cocinando pociones y brebajes, haciendo maleficios, desenterrando muertos, volando sobre bestias o llevadas en las espaldas por los demonios. La brujería era condenada como herejía: "De este modo, la hechicería fue incluida en el ámbito de la herejía. Como el inquisidor Bernardo Gui observó aproximadamente en 1320, la hechicería insinúa el pacto, y el pacto insinúa herejía, que entra en la juriscicción de la Inquisición" ${ }^{122}$.

Se creía en reuniones secretas, ritos de iniciación, adoración del diablo, orgías, infanticidio y canibalismo ${ }^{123}$, temas presentes en la iconografía. Tal actividad era vista como algo reprobable, como resalta el Malleus Maleficarum, escrito en 1484:

\footnotetext{
${ }^{121}$ E. H. Gombrich, Meditações sobre um cavalinho de pau e outros ensaios sobre a teoria da arte (São Paulo: EDUSP, 1999), 105.

122 Jeffrey Burton Russel, Lúcifer. O Diabo na Idade Média (São Paulo: Madras, 2003), 289. TE.

${ }^{123}$ Jeffrey Richards, Sexo, Desvio e Danação (Río de Janeiro: Jorge Zahar, 1992), 88.
} 
Es preciso observar especialmente que esa herejía [la de la brujería] difiere de todas las demás porque en ella no se hace solamente un pacto tácito con el diablo, sino un pacto perfectamente definido y explícito que ultraja al Creador y que tiene por meta profanarlo al extremo y extinguir sus criaturas (...). De todas las supersticiones, es [la] más vil, la más maléfica, y [la] más hedionda; su nombre latino maleficium, significa exactamente practicar el mal y blasfemar contra la fé verdadera (Maleficae dictae a maleficiendo, seu a male de fide sentiendo) ${ }^{124}$.

${ }^{124}$ Heinrich Kramer y James Sprenger, Malleus Maleficarum. O Martelo das Feiticeiras, (Río de Janeiro: Rosa dos Tempos, 1993), Questão II, 77. TE. Resaltados del autor. 


\section{Figura 14}

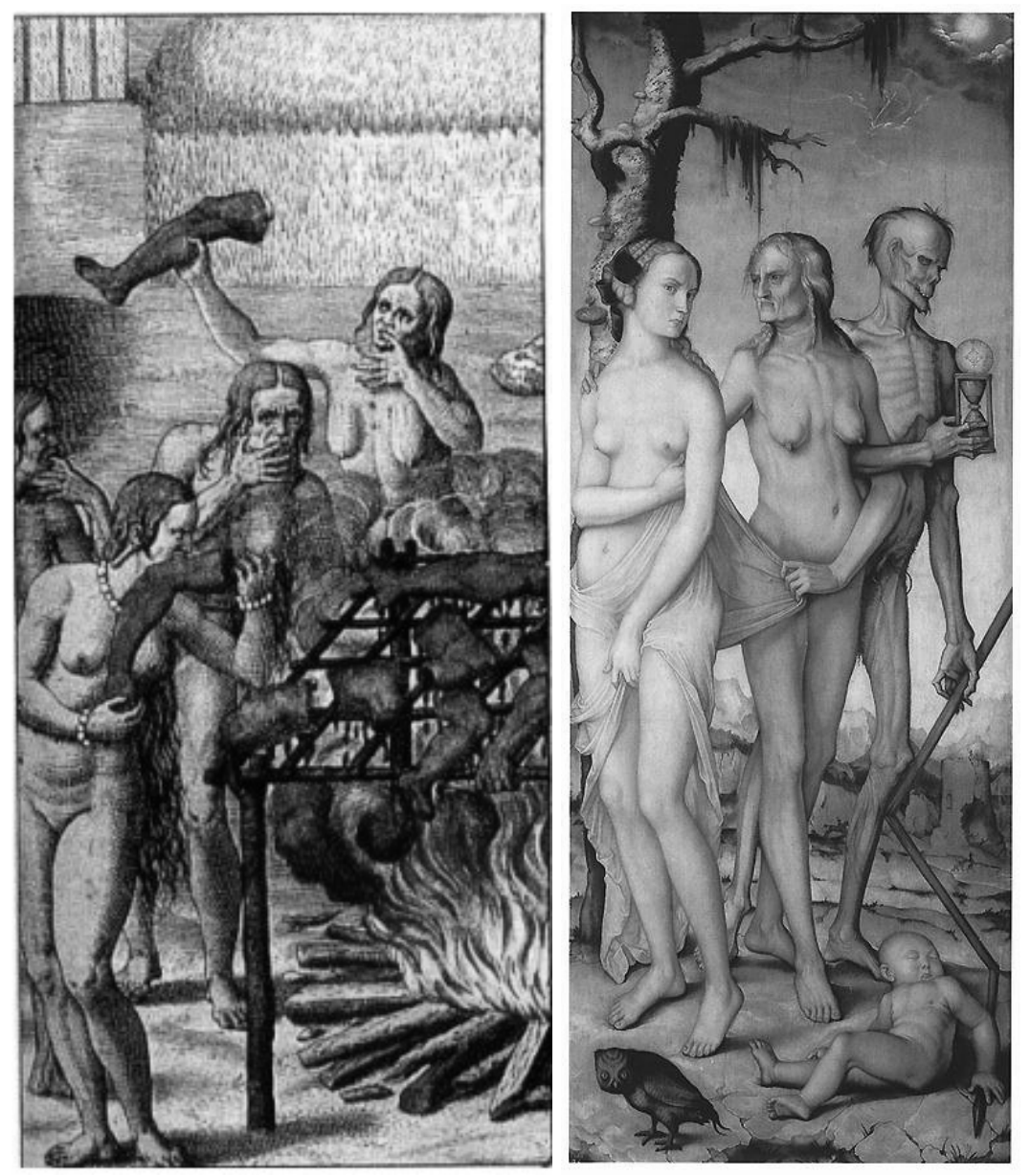

Izquierda: Detalle de las mujeres tupinambá, preparación de la carne humana. Theodore de Bry, America Tertia Pars (Frankfurt, 1592), 125. Grabado en cobre. Derecha: Las tres edades de la mujer y la muerte. Hans Bandung, óleo sobre madera, 151 x 61 cm, 1539. 
Tal obra explica el horror que se sentía por la bruja, porque ella tenía que renunciar al cristianismo, blasfemar, hacer un pacto y entregarse al demonio, en fin, practicar el mal para poder obtener beneficios. Era atributo de las brujas renunciar a la fe católica, practicar el maleficio, el sacrificio y el consumo de niños ${ }^{125}$, participar en las orgías y todo tipo de lujuria ${ }^{126}$, acusaciones estas que eran comunes en las herejías. Y hasta el propio cristianismo fue acusado de canibalismo en sus primeros siglos ${ }^{127}$.

Es importante llamar la atención acerca del protagonismo femenino en los escritos, en los manuales y, especialmente, en la iconografía sobre la brujería. ¿Por qué la iconografía está dominada por la presencia de la mujer? Se creía que la mujer era disimulada, más propensa que el hombre a caer en el pecado y a ceder a las artimañas del demonio, un ser inferior y débil, un animal imperfecto, una figura relacionada con el vicio y la falta de moderación, términos usados por los inquisidores Heinrich Kramer y James Sprenger, que sintetizan las razones de la siguiente forma:

... para explicar el mayor número de mujeres supersticiosas que de hombres. Y la primera está en su mayor credulidad; y, ya que el principal objetivo del diablo es corromper la fe, prefiere entonces atacarlas (...). La segunda razón es que las mujeres son, por naturaleza, más impresionables y más propensas a recibir la influencia del espiritu incorpóreo (...). La tercera razón es que, poseedoras de una lengua traicionera, no se abstienen de contarles a sus amigas todo lo que aprenden a

125 Los emperadores romanos, para justificar sus persecuciones contra la fuerza desestabilizadora del cristianismo, se apoyaron en el argumento de que los cristianos devoraban a los recién nacidos en sus cultos en las catacumbas: "Recibid el cuerpo y la sangre", esto, en los siglos II y III. Lo curioso es que cuando el cristianismo pasó a la institucionalidad y al control temporal, usó argumentos similares contra las minorías desestabilizadoras desde el siglo XIII, como ocurrió con los albingenses, con los templarios en Francia y con las brujas, en el siglo XVI, que eran quemadas bajo la acusación de usar en sus rituales grasa de bebé. En el mundo protestante, la historia se repitió en el siglo XVII. En el continente americano, durante la época de la conquista y la colonización, la "guerra justa" contra los indios se legitimaba con el combate a pueblos caníbales primitivos, adoradores del demonio, que sacrificaban y devoraban a sus enemigos, especialmente las indias viejas.

${ }^{126}$ Véase el estudio clásico de Carlo Ginzburg sobre el Sabbat y la brujería, História Noturna. Decifrando o Sabá (São Paulo: Companhia das Letras, 1991).

127 Acusaciones de orgía, incesto, infanticidio y canibalismo se encuentran en las ceremonias del Bacchanalia romano, en las acusaciones de Antiocus IV Epifanes contra los judíos, en las romanas contra los primeros cristianos y en las cristianas contra los gnósticos y maniqueístas. Russel, Lúcifer, 287. 
través de las artes del mal, y por ser débiles, encuentran modo fácil y secreto de justificarse a través de la brujería ${ }^{128}$.

Desde la baja Edad Media, la bruja era relacionada con los pecados capitales y con con los excesos, en especial con la lujuria. En el siglo XII, el cronista Guilherme de Malmesbury describe las brujas como golosas, lascivas y sin límite para sus desviaciones $^{129}$. El odio y la misoginia refuerzan en la mujer características negativas, como ser más carnal y ser creación imperfecta de una costilla curva ${ }^{130}$, lo que explicaría su debilidad y su perversidad. Uno de los principales papeles de la mujer en el Antiguo Testamento es el de instrumentum diaboli, instrumento que causa la perdición del ser humano ${ }^{131}$. El estereotipo de la mujer fea, decrépita y vieja será la encarnación del vicio, y ella será la aliada de Satán, con lo que despierta el miedo en el occidente cristiano ${ }^{132}$. Imágenes de este tipo serán representadas incesantemente, en especial en el siglo XVI.

La asociación de las imágenes de indias y brujas no es gratuita. Charles Zika demuestra las conexiones entre la iconografía del canibalismo de los amerindios y la iconografía de la brujería del Viejo Mundo después de la primera mitad del siglo $\mathrm{XVI}^{133}$. De acuerdo con este autor, las imágenes del canibalismo del Nuevo Mundo harían renacer y alterarían las imágenes de la brujería europea, integrando en ellas características de las representaciones caníbales de los amerindios:

Fue solamente en la segunda mitad del siglo XVI, al parecer, que comenzó a establecerse un vínculo visual entre el canibalismo de las brujas y el de Saturno. No se han encontrado representaciones visuales de brujas cocinando o comiendo carne humana, anteriores al final del siglo XVI. Es interesante que, desde entonces, en las fuentes escritas, tales como los tratados de brujería y las narraciones de procesos por brujería, el canibalismo de las brujas se refiere a esto. Y el canibalismo en general fue un tropo común en las representaciones literarias de las culturas extrañas y exóticas en la Edad Media tardía. En el proceso sorprendentemente lento mediante el cual el canibalismo se convirtió en parte de las representaciones visuales de la brujería, la figura de Saturno parece haber tenido ciertamente un rol, aun si la importancia de este rol aún no está clara. Los gravados de Crispin de Passe, Henri Leroy y Jan Sadeler en las décadas de 1580 y 1590, sugieren que inicialmente se

${ }^{128}$ Kramer y Sprenger, Malleus Maleficarum, "Questão VI. Sobre as Bruxas que copulam com Demônios. Por que principalmente as Mulheres se entregam às Supertições Diabólicas", 116. Resaltados del autor. TE.

${ }^{129}$ Richards, Sexo, 83.

${ }^{130}$ Kramer y Sprenger, Malleus Maleficarum, 116.

${ }^{131}$ Mario Pilosu, A Mulher, a Luxúria e a Igreja na Idade Média (Lisboa: Estampa, 1995), 29.

${ }^{132}$ Delumeau, História, 347 y Raminelli, Imagens, 102.

133 "Na tradição ocidental, o canibalismo possui uma estreita relação com o deus Saturno, conexão que unia as bruxas da Europa e os canibais da América, ambos filhos de Saturno. Essa evidencia tornou mais nítida a semelhança entre seus comportamentos”. Ibídem, 92. 
pudo haber establecido una conexión entre los caníbales amerindios y la figura de Saturno. Esto pudo haberse facilitado por la popularidad de las representaciones visuales de los amerindios como "salvajes" caníbales de la década de 1530 y especialmente después de la década de $1550^{134}$.

Hasta mediados del siglo XVI, apenas las fuentes textuales hacían referencia a estas prácticas antropofágicas de las brujas. De la misma forma que Zika comprueba el "renacimiento" de la iconografía sobre brujería en Europa a partir de la iconografía sobre antropofagia del Nuevo Mundo, se hace muy claro que en las imágenes los indios y, específicamente, las viejas de los festines caníbales también adquirieron características de las brujas europeas, no solo en los textos de las crónicas sino también en las representaciones iconográficas. Los rasgos y los tratamientos de los cuerpos de las viejas indias denotan la influencia que Theodoro De Bry tuvo, para retratarlas, de otros artistas europeos. No puede olvidarse que el maestro de De Bry, Etienne Delaune, fue discípulo de Durero, al igual que Baldung, que además tenían gusto por temáticas del Sabbat. El contraste entre las jóvenes y las indias viejas tiene que ver con la moral, ya que una vida de pecado y de consumo de carne humana lleva a la degeneración del cuerpo. Los humores, como la bilis negra, que afectan el interior y repercuten en los comportamientos, también muestran sus efectos en el exterior del cuerpo. Desde la Edad Media, la teoría de los humores tuvo amplia difusión en diferentes círculos profesionales, como puede ser percibido en los Diálogos, tratado dirigido para artistas del siglo XVII por Vicente Carducho:

Estos efectos causados en el cuerpo exterior tienen a veces correspondencia y alusión a lo interior, causado el uno y el otro de la calidad del humor destemplado por mucha o poca cantidad de materia, inclinando algo aquella destemplanza los afectos humanos, unos a lo bueno y en otros a lo contrario; cual inclina al mando y al gobierno, cual, a servidumbres viles y a otras mil diferencias, como vemos de ordinario en las singulares inclinaciones que solicitan sus naturales, cuando el libre albedrío regulado por la razón y luz, que profesamos, no la enmienda, y con virtudes positivas oscurece defectos naturales ${ }^{135}$.

La antítesis de las jóvenes bellas y voluptuosas son las viejas deformadas, arrugadas y flacas, resultado de sus costumbres salvajes. El Malleus Maleficarum llama la atención acerca de las pasiones que ejercen modificaciones en el cuerpo:

\footnotetext{
${ }^{134}$ Charles Zika, "Body Parts, Saturn and Cannibalism: Visual Representations of witches Assemblies in the Sixteenth Century" (artículo presentado para las memorias del seminario "Le Sabbat des Sorciers em Europe (XVe-XVIIIe Siècles)", École Normale Superieure de Fontenay - ST. Cloud, 4-7 de noviembre 1992), 15. TE.

${ }^{135}$ Vicente Carducho, Diálogos de la pintura. Su defensa, origen, esencia, definición, modos y diferencias, edición, prólogo y notas de Francisco Calvo Serraller (Madrid: Turner, 1977), 183.
} 
Y el cuerpo humano es más noble que cualquier otro cuerpo, pero como las pasiones de la mente humana se modifican y ora se inflaman, ora se enfrían -cuando se siente rabia o miedo, por ejemplo-, ese mismo cuerpo puede sufrir modificaciones más profundas, como los efectos de las dolencias o la muerte, los cuales, por su fuerza, pueden transformar mucho un cuerpo material ${ }^{136}$.

Las imágenes de las viejas simbolizan los peores vicios, como el caso de las brujas; las indias viejas muestran el cuerpo deteriorado debido a una vida entera entregada al vicio y al pecado. En el tratado Da Pintura del siglo XV Leon Battista Alberti ya explicaba que el artista, al hacer sus obras, debería tener en cuenta la estrecha relación entre el cuerpo y el alma:

Mas los movimientos del alma se conocen por los movimientos del cuerpo. Vemos cómo las personas tristes, a quienes la preocupación aflige y el pensamiento asedia, andan con sus fuerzas y sentimientos embotados, manteniéndose lentos y perezosos, con sus miembros pálidos e inseguros. Los melancólicos tienen la frente fruncida, cabeza lánguida, todos sus miembros decaen como si estuviesen cansados y descuidados. En los irritados, con todo, la ira, incitando al alma, entumece de cólera los ojos y el rostro y enciende sus colores; todos los miembros, en cuanto mayor es la furia, más se lanzan en libertad ${ }^{137}$.

Theodoro De Bry y los otros artistas que pintan, dibujan o graban mujeres viejas tienen en cuenta esa relación alma-cuerpo. Si este último está decaído y desgastado es porque el individuo tiene un alma y una mente sometida a los vicios, al demonio y al pecado, como en el caso de las indias tupinambá y su gula por la carne humana. Las cartas jesuíticas son detalladas en las asociaciones demoníacas, como escribe el padre Azpilcueta Navarro:

Yendo yo a visitar una aldea, vi que de la carne que cocinaban en un gran caldero, y al tiempo que llegué, sacaban fuera una porción de brazos, pies y cabezas de gente, que era cosa abominable de verse, y seis o siete mujeres, que con trabajo se tenían en pie, danzaban alrededor, escupiendo al fuego, que parecían demonios en el infierno ${ }^{138}$.

La Gula y la Lujuria son consideradas pecados capitales para los cristianos protestantes y católicos, por ser pecados carnales que ensucian el alma ${ }^{139}$. Son llevados a un nivel abominable por los tupinambá a los ojos del europeo, como apuntan Bernardette Bucher, Ana María Belluzzo y Ronald Raminelli. Aunque parezca irreversible, el destino trágico del tupinambá, es decir, la degeneración de su cuerpo y de su alma, así como la pérdida de su humanidad, por causa de sus costumbres abominables, no está consumado. En los grabados de Theodoro De Bry

\footnotetext{
${ }^{136}$ Kramer y Sprenger, Malleus Maleficarum, 67. TE.

${ }^{137}$ Alberti, Da Pintura, lib. 2, 41, 114. TE.

${ }^{138}$ Cartas Avulsas, 77-78. Resaltados del autor. TE.

${ }^{139}$ Pilosu, A Mulher, 58.
} 
la posibilidad de transformación del hombre aún es una opción, como afirma Thereza Baumann. Esta esperanza de salvación está confirmada por el padre Claude D'Abbeville:

¡Mire a qué apogeo de crueldad el diablo, bárbaro verdugo de las almas ciegas, llevó, por entre las tinieblas de la infidelidad, a ese pueblo pagano! A pesar de todo, Dios, en su infinita misericordia, se conmovió de ellos en medio de su ceguera odiosa y nos permitió que les diéramos a conocer la abominación de esa costumbre tan diabólica y tan contraria a la voluntad de Tupã que nos ordena amar a nuestros enemigos $^{140}$.

La práctica de la antropofagia, vicio contrario al orden natural y abominable a los ojos europeos, lleva a los viajeros, cronistas y artistas a dotar de atributos monstruosos al individuo que la practica ${ }^{141}$. La degeneración de los cuerpos de las indias viejas de rostros anómalos y cuerpos deformados sería la prueba de estos atributos degradantes, resultado de una vida licenciosa. A pesar de todo, la conversión de ese gentío al cristianismo podría generar la posibilidad de transformación y de salvación de sus almas.

\section{Conclusión}

La cosmovisión del europeo de los siglos XV y XVI chocó con una realidad desconocida, como era el Nuevo Mundo y sus habitantes. Para asimilar esta nueva realidad fue preciso la existencia de coordenadas familiares para poder aprenderla, esquemas que el artista encontró en su propia tradición escrita: en la Biblia, en los autores clásicos y cristianos, en los tratados, crónicas y relatos de viajes medievales de los siglos XIII-XIV, entre otros, y también en la tradición iconográfica: las imágenes del hombre salvaje de los bosques: el feroz y el buen salvaje; del Paraíso: Adán y Eva; de la Edad Dorada, de los seres y razas fantásticas ${ }^{142}$; de las fábulas y de las maravillas del Oriente, que ofrecieron los referentes, las bases para componer las imágenes del indio y del canibalismo de los siglos XV y XVI.

Las imágenes sobre la antropofagia realizadas en la primera mitad del siglo XVI asociaron el consumo de carne humana a banquetes y festines, es decir, al placer gastronómico, como actitudes cotidianas de los amerindios. Las mismas no tenían en cuenta la etnografía, separando estas costumbres de sus aspectos rituales. Los artistas de los grabados se inspiraron en su propia cotidianidad y en la tradición para componer por analogía las escenas del Nuevo Mundo, siendo que los elementos que componían estas escenas ya existían antes de la llegada de Colón. A

${ }^{140}$ D’Abbeville, História, 234. Resaltados del autor. TE.

${ }^{141}$ Kappler, Monstros, 231.

${ }^{142}$ Aquí concuerdo con las profesoras Susan Milbrath y Bernadette Bucher. 
partir del contacto con los pueblos amerindios, estos esquemas preconcebidos son proyectados, adaptados y repetidos.

Después de la segunda mitad del siglo XVI, las representaciones iconográficas comienzan a migrar de lo maravilloso medieval a lo exótico colonial. Con Staden, Léry, Thevet y De Bry, la antropofagia gana connotaciones de ritual mágicoreligioso; y como estos europeos están más atentos a comprender costumbres y formas de vida, las representaciones visuales cambian. Los rituales antropofágicos respondían, en el caso de los tupinambá, no al gusto gastronómico y sí a un sentimiento de venganza -vengar al enemigo y devorarlo, porque él y los suyos lo harán de la misma forma-. A pesar de esto, las características de ritual acaban siendo ignoradas al momento de representar el festín antropofágico propiamente dicho, en el cual el gusto gastronómico por carne humana por parte de los amerindios se impone. En suma, son imágenes de la antropofagia herederas de la tradición medieval y de lo maravilloso.

Staden, Léry y Thevet estuvieron en el Nuevo Mundo; Theodoro De Bry no. Además de eso, él era editor y sus imágenes debían atender más al público en general, no teniendo ningún compromiso etnográfico. Ello no significa que los grabados de Staden, Léry y Thevet fueran más correctos que los de De Bry por el hecho de haber estado en contacto con los tupinambá, ya que en esta época el artista no tenía ningún compromiso con la realidad o con la exactitud pictórica; pero este es otro tema de investigación.

De Bry, por ser un artista talentoso, esforzado y cuidadoso, copió muchos de estos detalles etnográficos registrados por los artistas y grabadores, en los cuales basó sus imágenes. Eso no le impidió mejorar las imágenes siguiendo criterios más de editor y artista, aumentando detalles y haciendo los grabados más interesantes y sofisticados para un público exigente y letrado, adaptando y creando nuevas imágenes, diferentes de sus modelos originales. A partir de los esquemas establecidos y aprendidos por su formación como grabador y dibujante, De Bry tuvo la capacidad de ser original, debido a su esfuerzo por dar unidad y establecer una apropiación visual sofisticada de los grabados de diferentes relatos y de varios artistas que le sirvieron de modelo y base para la colección Grandes Viajes. Estos elementos dan unidad y están relacionados básicamente con dos aspectos: primero, con los fondos, más elaborados con el uso de la perspectiva y llenado del espacio alrededor de las figuras, a diferencia de los xilograbados originales, que la mayoría de las veces permanecían en blanco; y segundo, con el uso de cánones elaborados para los cuerpos de los indios, que permitieron una identidad visual.

En el caso de la America Tertia Pars, los elementos originales de De Bry no se restringen a los cuerpos o a los fondos; la presencia y el destaque de las mujeres en los diferentes episodios de los grabados y los detalles crueles, minuciosos y 
mórbidos de la preparación y consumo de carne humana, en las escenas de antropofagia, alcanzaron la apoteosis del horror con el flamenco e impresionaron y chocaron a su sociedad. De Bry, al combinar lo exótico, lo erótico y lo macabro de las escenas con los cánones renacentistas, convirtió su obra en un referente obligatorio para artistas que deberían representar indios y escenas antropofágicas. Tanto, que aún hoy sus grabados continúan siendo una referencia visual de los grupos amerindios del siglo XVI.

Los cuerpos de los indios renacentistas de Theodoro de Bry muestran la desnudez como estado natural ideal, de la misma forma que los indios de los grabados del relato de Jean de Léry (1578), en los cuales el estado natural es tenido como verdad esencial, diferente de lo artificial de la sociedad europea, y es apreciado como virtud en la simplicidad del desnudo. En los grabados de De Bry, el pudor, en las pocas veces que es registrado, es manifestado por el alemán Hans Staden, nunca por los indios.

El cuerpo arrugado y decadente de las indias viejas correspondería a un reflejo de su interior, de su alma. Sería un llamado de alerta a las prácticas salvajes, es decir, que consumir carne humana llevaría al deterioro del cuerpo y a la pérdida del alma. La lectura estructuralista de Bucher en el contexto neoplatónico de De Bry tiene mucho sentido, pero no puede limitarse a una simple condena. La interpretación de esta autora solo considera las narraciones de Staden y Léry y deja de lado otras fuentes. A pesar de todo, no es posible negar el estigma negativo de la vieja, reafirmado constantemente en las diferentes crónicas.

Pero también creo que las indias de senos caídos representan una reflexión sobre la transitoriedad de la existencia y sobre la finitud del mundo y de las cosas materiales: el cuerpo, la belleza y la juventud acaban. No es solo una acusación de De Bry, como fervoroso reformado, contra la antropofagia, sino también contra cualquier vicio y pecado. No puede olvidarse a quién iba dirigida su obra. En esta perspectiva, es pertinente la lectura de Baumann, pues las imágenes de las viejas indias también significan transformación, son un llamado a los cristianos reformados a venir a evangelizar el Nuevo Mundo y a cambiar la situación de dominio del pecado. Además, estas modificaciones del cuerpo no corresponden solo a cuestiones morales, sino también a la crisis surgida en el siglo XVI, que cuestionó algunos conceptos del Renacimiento, especialmente los rígidos cánones matemáticos, expresión de la belleza perfecta para representar el cuerpo. A esos conceptos, el Manierismo respondió con sus cuerpos más alargados (de 10 cabezas, lo "normal" era tener 8), con las famosas figuras serpentinas ${ }^{143}$, cuerpos en formas

${ }^{143}$ Baumann, "Thesaurus", 310-313. 
de $\mathrm{S}$ o lengua de fuego ${ }^{144}$, cuerpos contorsionados y curvados, en rechazo a la "tiranía" de la belleza matemática, de la perspectiva, que retornando a una forma medieval de componer que agrupa formas en el primer plano, y seguen al instinto, al sentimiento, más que a la razón ${ }^{145}$.

\section{Bibliografía}

Alberti, Leon Battista. Da Pintura. Campinas: Unicamp, 1989.

Alexander, Michael, ed. Discovering the New World. Based on the works of Theodore de Bry. Londres: Harper \& Row, s. f.

Anchieta, José. Cartas: informações, fragmentos históricos e sermões. Belo Horizonte y São Paulo: Itatiaia; Universidade de São Paulo, 1988.

Ariès, Philippe. O Homem Perante a Morte. Mem Martins: Publicações EuropaAmerica, 1988.

Argan, Giulio Carlo. Clássico Anticlássico. O Renascimento de Brunelleschi a Bruegel. São Paulo: Companhia das Letras, 1999.

Baumann, Thereza. "Thesaurus de Viagens. Theodoro de Bry: identidade e alteridade na iconografia do século XVI". 2 vols. Tesis doctoral, Universidad Federal Fluminense, Niterói, Brasil, 2001.

Belluzzo, Ana Maria de Morais. "A lógica das imagens e os habitantes do Novo Mundo". En Índios no Brasil, ed. L. D. B. Grupioni, 47-58. Brasilia: Ministério da Educação e do Desporto, 1994.

O Brasil dos Viajantes. 3 ed. Río de Janeiro: Objetiva; Metalivros, 2000 .

Benzoni, Girolamo. Historia del Mondo Nuevo. 1565.

\footnotetext{
${ }^{144}$ Erwin Panofsky, Idea: A Evolução do conceito de Belo (São Paulo: Martins Fontes, 2000), 75 .

${ }^{145}$ Sobre el manierismo, consúltese Arnold Hauser, Maneirismo, a crise da renascença e o surgimento da arte moderna (São Paulo: Perspectiva, 1993); Giulio Carlo Argan, Clássico Anticlássico. O Renascimento de Brunelleschi a Bruegel (São Paulo: Companhia das Letras, 1999); Panofsky, Idea; E. H. Gombrich, Norma e Forma (São Paulo: Martins Fontes, 1990).
} 
Bouyer, Marc y Jean Paul Duviols. "Les Grands Voyages de Théodore de Bry". En Le Théâtre du Nouveau Monde. Les Grands Voyages de Théodore De Bry, Theodore de Bry. París: Gallimard, 1992.

Bry, Théodore de. Admiranda Narratio. 1590. . America Tertia Pars. Frankfurt, 1592. . America Pars Qvarta. 1594.

. Le Théâtre du Nouveau Monde. Les Grands Voyages de Théodore De Bry. París: Gallimard, 1992.

Le Théâtre du Nouveau Monde. Les Grands Voyages de Théodore De Bry. París: Gallimard, 1992.

Bucher, Bernadette. Icon and Conquest. A structural analysis of the illustrations of de Bry's Great Voyages. Chicago y Londres: The University of Chicago Press, 1981.

Cardim, Fernão. Tratados da Terra e Gente do Brasil. Vol 2. Do princípio e origem dos índios. Lisboa: Comissão Nacional para as Comemorações dos Descobrimentos Portugueses, 1997.

Carducho, Vicente. Diálogos de la pintura, Diálogo Quarto.

Cartas Avulsas, 1550-1568. Azpilcueta Navarro e Outros. Belo Horizonte y São Paulo: Itatiaia; Universidade de São Paulo, 1988.

D’Abbeville, Claude. História da Missão dos Padres Capuchinhos na Ilha do Maranhão e terras circunvizinhas. Belo Horizonte y São Paulo: Itatiaia; Universidade de São Paulo, 1975.

Del Priore, Mary. Esquecidos por Deus: Monstros no mundo europeu e Iberoamericano (Séculos XVI-XVIII). São Paulo: Companhia das Letras, 2000.

Delumeau, Jean. História do Medo no Ocidente, 1300-1800. Uma cidade sitiada. São Paulo: Companhia das Letras, 1989.

O Pecado e o Medo. A culpabilização no Ocidente (Séculos XIII-XVII). Bauru: EDUSC, 2003. 
Duviols, Jean-Paul. "Théodore de Bry et ses modèles français", Caravelle (Toulouse, Francia), 58 (1992): 7-16.

Eisentein, Elizabeth L. A Revolução da Cultura Impressa. Os primórdios da Europa Moderna. São Paulo: Ática, 1998.

Fausto, Carlos. "Fragmentos de história e cultura tupinambá. Da etnologia como instrumento crítico de conhecimento etno-histórico". En História dos Índios do Brasil, comp. Manuela Carneiro da Cunha, 381-396. São Paulo: Companhia das Letras; Secretaría Municipal de Cultura; FAPESP, 1992.

Fernandes, Florestan. A Função social da Guerra na Sociedade Tupinambá. São Paulo: Universidade de São Paulo, 1970.

Forge, Jacques. "Naissance d'une image". En L'Amérique de Théodore de Bry. Une collection de voyages Protestante du XVIe siècle, dir. Michèle Duchet. París: Centre National de la Recherche Scientifique, 1987.

Gândavo, Pero de Magalhães de. A primeira História do Brasil. História da província Santa Cruz a que vulgarmente chamamos Brasil (Río de Janeiro: Jorge Zahar, 2004).

Ginzburg, Carlo. História Noturna. Decifrando o Sabá. São Paulo: Companhia das Letras, 1991.

Giucci, Guillermo. Viajantes do Maravilhoso. O novo Mundo. São Paulo: Companhia das letras, 1992.

Gombrich, H. E. Arte e Ilusão. São Paulo: Martins Fontes, 1989.

. Meditações sobre um cavalinho de pau e outros ensaios sobre a teoria da arte. São Paulo: EDUSP, 1999.

Norma e Forma. São Paulo: Martins Fontes, 1990.

Hauser, Arnold. Maneirismo, a crise da renascença e o surgimento da arte moderna. São Paulo: Perspectiva, 1993.

Holanda, Sergio Buarque de. Visão do paraíso: Motivos Edênicos no Descobrimento e Colonização do Brasil. São Paulo: Companhia Editora Nacional, 1969. 
Kappler, Claude. Monstros, demônios e encantamentos no fim da Idade Média. São Paulo: Martins Fontes, 1994.

Kramer, Heinrich y James Sprenger. Malleus Maleficarum. O Martelo das Feiticeiras. Río de Janeiro: Rosa dos Tempos, 1993.

Kupperman, Karen Ordahl. Indians and English. Facing off in Early America. Ithaca y Londres: Cornell University Press, 2000.

Lestringant, Frank. "L'automne des cannibales ou les outils de la conquête". En L'Amérique de Théodore De Bry. Une collection de voyages protestante du XVIe siècle, dir. Michèle Duchet, 69-104. París: Centre National de la Recherche Scientifique, 1987.

. O Caníbal: grandeza e decadência. Brasilia: UNB, 1997.

Léry, Jean de. Viagem à terra do Brasil. Belo Horizonte y São Paulo: Livraria Itatiaia; Universidade de São Paulo, 1980.

Luins Jr., William M. Prints and visual communication. Cambridge: The MitPress, 1982.

Mason, Peter. Infelicities. Representation of the Exotic. Baltimore, Estados Unidos: The Johns Hopkins University Press, 1998.

Métraux, Alfred. A Religião dos Tupinambás e suas relações com as demais tribos tupi-guaranis. São Paulo: Ed. Nacional; Universidade de São Paulo, 1979.

Montaigne, Michel de. Ensaios. Río de Janeiro, Porto Alegre y São Paulo: Globo, 1961.

Mukerji, Chandra. From Graven Images. Patterns of Modern Materialism. Nueva York: Columbia University Press, 1983.

Pacheco, Francisco. El arte de la pintura. 1644; Madrid: Editorial Cátedra, 1990.

Panofsky, Erwin. Estudos de iconología. Madrid: Alianza Universidad, 1998. Idea: A Evolução do conceito de Belo. São Paulo: Martins Fontes, 2000.

Pigafetta, Antonio. La primera vuelta al mundo. Las mejores crónicas marinas I. Buenos Aires: Ameghino, 1998. 
Pilosu, Mario. A Mulher, a Luxúria e a Igreja na Idade Média. Lisboa: Estampa, 1995.

Raminelli, Ronald. Imagens da Colonização. São Paulo: Jorge Zahar, 1996.

“Tupinambá". En Dicionário do Brasil Colonial (1500-1808), dir. Ronaldo Vainfas. Río de Janeiro: Objetiva, 2000.

. "Eva Tupinambá". En História das Mulheres no Brasil, ed. Mary del Priore. São Paulo: Contexto; Unesp, 2001.

Reale, Giovanni y Dario Antiseri. História da Filosofia. Antigüidade e Idade Média. 2 vols. São Paulo: Paulus, 1990.

Richards, Jeffrey. Sexo, Desvio e Danação. Río de Janeiro: Jorge Zahar, 1992.

Russel, Jeffrey Burton. Lúcifer. O Diabo na Idade Média. São Paulo: Madras, 2003.

Salvador, fray Vicente do. História do Brasil 1500-1527. São Paulo: Melhoramentos, 1965.

Silva Galdames, Osvaldo. "El mito de los comedores de carne humana en América", Revista Chilena de Humanidades (Santiago), 11 (1990).

Souza, Gabriel Soares de. Tratado descritivo do Brasil em 1587. Belo Horizonte: Itatiaia, 2000.

Staden, Hans. Viagem ao Brasil. Versão do texto de Marburg de 1557. Río de Janeiro: Academia Brasileira de Letras, 1988.

Thevet, André. As Singularidades da França Antártica. Belo Horizonte y São Paulo: Livraria Itatiaia; Universidade de São Paulo, 1978.

Vasconcellos, Simão de. Chronica da Companhia de Jesus do Estado de Brasil. Río de Janeiro: Typographia de João Ignácio da Silva, 1864.

Vespuccio, Américo. Novo Mundo. As cartas que batizaram a América. São Paulo: Planeta, 2003.

Zika, Charles. "Body Parts, Saturn and Cannibalism: Visual Representations of witches Assemblies in the Sixteenth Century". Artículo presentado para las memorias del seminario "Le Sabbat des Sorciers en Europe (XVe-XVIIIe 
Siècles)". École Normale Superieure de Fontenay - ST. Cloud, 4-7 de noviembre 1992.

Fecha de recepción: 2 de mayo de 2005.

Fecha de aceptación: 23 de agosto de 2005. 